\title{
Miocene development of alpine glacial relief in the Patagonian Andes, as revealed by low-temperature thermochronometry
}

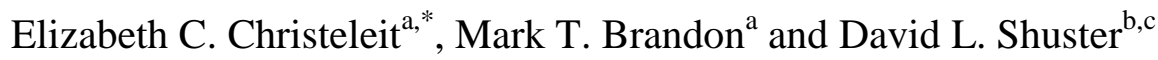

Keywords: apatite; (U-Th)/He thermochronometry; ${ }^{4} \mathrm{He} /{ }^{3} \mathrm{He}$; Patagonian Andes; glacial erosion; landscape evolution

Abstract 
Apatite thermochronometry and synthetic maps of ages and rates for thermochronometric data are used to estimate the timing of incision of valley relief in the Andes. Central Patagonia offers a unique location to study the feedbacks between long-term climate, topography, and erosion due to the high relief and well-resolved mid-latitude glacial history. New apatite (U-Th)/He ages from two vertical transects and two ${ }^{4} \mathrm{He} /{ }^{3} \mathrm{He}$ release spectra in the fjord network around $47^{\circ} \mathrm{S}$ reveal fast cooling (15-30 ${ }^{\circ} \mathrm{C} / \mathrm{Ma}$ ) from $\sim 10$ to $5 \mathrm{Ma}$. Samples currently at the surface cooled below $\sim 35$ ${ }^{\circ} \mathrm{C}$ by $\sim 5 \mathrm{Ma}$, indicating slow cooling and little erosion in those regions since $5 \mathrm{Ma}$. We show that these very low-temperature thermochronometric data are useful indicators of changes in topography, and insensitive to deep thermal processes, such as migration of the Chile triple junction. Map-based predictions of the thermochronometric signatures of disparate topographic scenarios show the distribution of sample data necessary to resolve the timing of relief change. Comparisons to predicted cooling ages and rates indicate that our new apatite He data are most consistent with a pulse of early glacial incision, with much of the observed valley relief in Patagonia carved between 10 and 5 Ma. Early onset of glaciation in Patagonia is supported by glacial till with bracketing ages of 7.4 and $5 \mathrm{Ma}$. We therefore conclude that the observed thermochronometric signal of fast cooling from 10 to $5 \mathrm{Ma}$ is likely due to an increase in valley relief coinciding with these early glaciations in the Andes. In other glaciated areas at lower latitudes, studies have found a dramatic increase in valley relief at $\sim 1 \mathrm{Ma}$. This timing has generated the idea that incision of glacial valleys may be related to the mid-Pleistocene transition, when the global glacial cycle changed from 40 to $100 \mathrm{ka}$ periods. Our results from a higher latitude indicate an alternative, that glacial valleys incised rapidly after the onset of alpine glaciation.

\section{Introduction}

Deep valleys and fjords, with relief of 1 to $2 \mathrm{~km}$, are common features of continental landscapes at latitudes poleward of $48^{\circ} \mathrm{N}$, and $42^{\circ} \mathrm{S}$. However, it is easy to overlook the extreme relief associated with these features, given that they are commonly concealed by water, ice, and sediment. Glacial erosion is unlike fluvial erosion, in that the long profile of the valley can cut well below base level at the outlet. This leads to glacially cut valleys that are "overdeepened",

53 where the middle reach is significantly deeper than sea level and the seaward outlet. This

54 situation is well known for fjords and glacially carved lakes (inland fjords). For example, the

55 deepest fjords in the world, Skelton Inlet in Antarctica, and Fjord Messier in southern Chile, 56 extend to $1933 \mathrm{~m}$, and $1468 \mathrm{~m}$, respectively, below sea level. 
58 Overdeepened valleys were recognized long ago as a geomorphic feature diagnostic of glacial

59 erosion (e.g. Ramsay, 1862). Notable research over the last several decades includes process-

60 based studies of their formation (e.g., Hooke, 1991; Alley et al., 2003; Kessler et al., 2008;

61 Headley et al., 2012), and geologic studies of fjord morphology and post-glacial fill (e.g.,

62 Montgomery, 2002; Glasser and Ghiglione, 2009; Dowdeswell and Vasquez, 2013). How glacial

63 valleys and fjords develop over time, and what role climate and tectonics play in controlling the

64 development of extreme valley relief remains unclear. Here, we focus on quantifying the timing

65 and rate of glacial valley formation in southern Chile.

67 Our understanding of glacial landscape development is limited by our ability to reconstruct pre68 glacial topography and glacial landforms through time. The low temperature sensitivity of the 69 apatite $(\mathrm{U}-\mathrm{Th}-\mathrm{Sm}) / \mathrm{He}$ and ${ }^{4} \mathrm{He} /{ }^{3} \mathrm{He}$ thermochronometric systems make these methods useful for 70 quantifying rates and timing of landscape change, e.g., in the evolution of fluvial valleys in the 71 Northern Andes and the Grand Canyon (Schildgen et al., 2010; Flowers and Farley, 2012, 72 respectively), and glacial valleys in the Coast Mountains of British Columbia, the Fiordland of 73 New Zealand, and the Swiss Alps (Shuster et al., 2005; Shuster et al., 2011; Valla et al., 2011, 74 respectively). In glacial landscapes, where geologic markers of landscape change are eroded by 75 subsequent glaciations, low-temperature thermochronometry offers perhaps the only method to 76 measure the evolution of valley incision on a geologic time scale.

78 Southern Chile $\left(\sim 47^{\circ} \mathrm{S}\right)$ preserves a relatively long history of alpine glaciations, where the earliest 
79 known glacial till lies between two basalt flows, with ages of $7.38 \pm 0.05$ and $5.04 \pm 0.04 \mathrm{Ma}$

80 (Fig. 1; Mercer et al., 1982; Ton-That et al., 1999). Mountain building and glacial erosion has

81 resulted in dramatic modern bedrock relief, bounded by the $\sim 4 \mathrm{~km}$ summit of Monte San Valentin

82 to $\sim 1.5 \mathrm{~km}$ below sea level at the deepest part of Fjord Messier. Northward migration of the Chile

83 triple junction and associated oblique subduction of the Chile ridge (Cande and Leslie, 1986) is

84 thought to play a dominant role in the cooling and heating history of upper crustal bedrock, and

85 relief development in the region (Haschke et al., 2006; Guillaume et al., 2013; Georgieva et al.,

86 2016). We show here, using thermal modeling, that the triple junction has had little influence on

87 temperatures in the shallow crust ( $<3 \mathrm{~km}$ depth). As a result, for this study area, low-temperature

88 thermochronometry records the thermal signal of erosion and relief change.

90 In this contribution, we explore various end-member hypotheses for the timing of glacial incision

91 in southern Chile and develop a method to study the thermochronometric signature of the

92 formation of valley relief over geologic timescales. Our method illustrates the ability of He

93 apatite methods to discriminate between disparate topographic histories. We compare predicted

94 cooling ages and rates for several end-member hypotheses of valley incision to our observed

95 apatite $(\mathrm{U}-\mathrm{Th}-\mathrm{Sm}) / \mathrm{He}$ and ${ }^{4} \mathrm{He} /{ }^{3} \mathrm{He}$ data from the fjords in central Patagonia $\left(\sim 47^{\circ} \mathrm{S}\right)$. The new

96 data require that glacial incision in southern Chile occurred between 10 and $5 \mathrm{Ma}$, coinciding

97 with previously recognized early glaciations in the region (Mercer et al., 1982; Ton-That et al.,

98 1999). Our results highlight the importance of relief formation in the long-term evolution of

99 glacial landscapes and suggest that glacial erosion proceeds rapidly after the onset of glaciation. 


\section{Central Patagonian Andes}

\subsection{Geomorphic setting}

103 There is a dense network of fjords and glacially carved lakes in southern Chile, which are deep 104 depressions fully surrounded by bedrock on all sides (Fig. 2). Fjord Messier is the most extreme 105 example, with a maximum depth of $1468 \mathrm{~m}$ below sea level (Araya-Vergara, 2008), and subaerial 106 topography that locally rises to $\sim 500 \mathrm{~m}$ above sea level. The relief and width of this valley is $1072000 \mathrm{~m}$ and $24 \mathrm{~km}$, respectively. For comparison, the Grand Canyon in Arizona has an average 108 valley relief of $1600 \mathrm{~m}$ and an average width of $16 \mathrm{~km}$. The seaward ends of the fjords terminate 109 abruptly at the inside limit of the continental shelf, with terminal sills that rise to within $100 \mathrm{~m}$ of 110 modern sea level. The lakes in the region are all overdeepened. The most extreme are Lago 111 O'Higgins/San Martín, Lago General Carrera/Buenos Aires, and Lago Pueyrredón/Cochrane, 112 which are cut to depths of $586 \mathrm{~m}, 313 \mathrm{~m}$, and $307 \mathrm{~m}$, respectively, below sea level (Fig. 1). All of 113 the rivers in the area are underfit, in that they are much too small to have cut their valleys. The 114 largest fluvial system, the Rio Baker (Fig. 2), presently cuts across the entire width of the Andes, 115 flowing from Lago Buenos Aires/General Carrera on the east of the Andes, to the Pacific Ocean 116 on the west side. Its course seems largely determined by interconnected glacial valleys.

118 At present, the North and South Patagonian icefields (NPI and SPI) collectively represent the 119 third largest glacial mass in the world $\left(21,000 \mathrm{~km}^{2}\right.$ area; Fig. 1). The distribution of Quaternary 120 moraines indicates that, during glacial epochs, the extent of ice was about 25 times larger than the 121 modern extent. These glacial maxima formed recurring ice caps, which covered the Patagonian 122 Andes from $36^{\circ} \mathrm{S}$ to $55^{\circ} \mathrm{S}$, with typical widths of $\sim 100-300 \mathrm{~km}$ (Fig. 1; Caldenius, 1932; 
123 Clapperton et al., 1993). While there is no independent data for when glaciation began in

124 Patagonia, the earliest known glacial tills in the region are bracketed by basalt flows of $7.38 \pm$

1250.05 and 5.04 $\pm 0.04 \mathrm{Ma}$, and $3.44 \pm 0.1$ and $3.32 \pm 0.1 \mathrm{Ma}$ (yellow stars in Fig. 1; Mercer et al.,

126 1982; Ton-that et al., 1999; Guivel et al., 2006). These deposits contain granitic cobbles sourced

127 from the Patagonian batholith $100 \mathrm{~km}$ to the west (Fig 1.; Mercer et al., 1982), suggesting that

128 these early glaciations also formed large ice caps. The modern equilibrium line altitude (ELA) of

129 glaciers in the North Patagonian icefield is estimated to be between $\sim 1000$ to $1300 \mathrm{~m}$ (Rivera et 130 al., 2007). Estimates of the paleo-ELA are complicated by the fact that during glacial epochs, a

131 lowering of temperature is accompanied by a northward migration of precipitation belts (for

132 estimates see discussion in Hulton et al., 1994).

\section{$134 \quad 2.2$ Tectonic setting}

135 The high topography of the Patagonian Andes was formed by back-arc thrusting and folding, 136 starting at $\sim 30 \mathrm{Ma}$ (see Ramos and Ghiglione, 2008 and references within). Blisniuk (2005)

137 estimates that the range reached its present height (summits higher than $1.5 \mathrm{~km}$ ) by $\sim 16 \mathrm{Ma}$. The 138 eastern frontal thrust faults became inactive by 8 Ma (Ramos, 1989), which suggests that surface 139 uplift by tectonic thickening has been insignificant since that time. Neotectonic activity on dextral 140 strike-slip faults has been identified in the Liquine-Ofqui Fault Zone northwest of the NPI and on

141 the eastern flank of the NPI (Cachet Fault; Georgieva et al., 2016). Georgieva et al. (2016) also 142 identify normal faults in the Exploradores Valley adjacent to Monte San Valentin, and at El

143 Salton along the Rio Baker. Interpretation of low-temperature thermochronometric data suggests

144 that the Cachet Fault and associated normal faults became active in the last 2-3 Ma (Georgieva et 
147 The study area includes two active volcanoes, Arenales and Lautaro (Fig. 2). Both have erupted 148 through the North and South Patagonian ice fields, and have formed small stratocones, built

149 directly on old bedrock. They are otherwise dwarfed by the bedrock topography. The highest 150 point in the landscape, Monte San Valentin $(4058 \mathrm{~m})$, is entirely underlain by Cretaceous and 151 Paleogene granites and older metamorphic rocks.

\subsection{Chile triple junction}

154 Plate reorganization in the middle Miocene led to the formation of the Chile triple junction along 155 the South American trench at $54^{\circ} \mathrm{S}$ at $\sim 20 \mathrm{Ma}$ (Cande and Leslie, 1986; Breitsprecher and 156 Thorkelson, 2009). This junction migrated northward to its present position at $46.5^{\circ} \mathrm{S}$ (Fig. 1) by 157 episodic subduction of Antarctic-Nazca spreading ridge segments (Cande and Leslie, 1986).

158 Discussion has focused on the influence of the triple junction on surface uplift, heating, and 159 deformation in the overriding plate (e.g., Cande and Leslie, 1986; Ramos and Ghiglione, 2008; 160 Guillaume et al., 2013; Braun et al., 2013). For example, Haschke et al. (2006) and Guillaume et 161 al. (2013) interpret apatite He and fission-track data from $47.5^{\circ} \mathrm{S}$ to $45.3^{\circ} \mathrm{S}$ as evidence for a pulse 162 of crustal heating from 12 to $5 \mathrm{Ma}$. In this scenario, topographic uplift and an associated increase 163 in surface erosion rates precedes the arrival of the triple junction offshore, because the triple 164 junction was south of $47^{\circ} \mathrm{S}$ until $\sim 6 \mathrm{Ma}$ (Fig. 1). 
166 To understand the influence of a thermal perturbation caused by subduction of progressively

167 younger oceanic lithosphere and the Chile ridge, we perform a 1D calculation of the thermal field

168 in the upper plate using a model developed by Molnar and England (1995) (Fig. 3; see Appendix

169 A in the supplementary material for details). Figure $3 \mathrm{c}$ shows the temperature profile through the

170 upper plate at a fixed point on the upper plate, $100 \mathrm{~km}$ from the trench. The temperature profile is

171 modeled over a $20 \mathrm{Ma}$ interval. Over this time interval, progressively younger oceanic crust was

172 subducted until the Chile ridge itself is at the trench at $8 \mathrm{Ma}$, followed by a gradual increase in

173 plate age at the trench (Fig. 3b).

174

175 Two important conclusions can be drawn from Figure 3. The first concerns the evolution of

176 upper-plate heating. Figure 3 shows gradual heating and subsequent cooling over a duration of 15

177 Ma. Regional heating caused by migration of the triple junction is protracted in time, and does

178 not produce a pulse of heating, as suggested by Guillaume et al. (2013). The reason is that heating

179 of the upper plate is not solely related to the subduction of the Chile ridge, but also to the young

180 age of the downgoing lithosphere adjacent to the ridge. The second conclusion concerns the

181 influence of ridge subduction on temperatures in the upper few kilometers of the crust $(\sim 2.5 \mathrm{~km})$,

182 which is relevant to apatite He thermochronometry. Figure 3 shows that a temperature increase of

$183 \sim 300{ }^{\circ} \mathrm{C}$ on the subduction thrust at $18 \mathrm{~km}$ depth causes a maximum change in temperature $\sim 20$

$184{ }^{\circ} \mathrm{C}$ at a depth of $3 \mathrm{~km}$. The overall conclusion is that a migrating triple junction has little influence

185 on the shallow temperature field, as relevant to the apatite He system. In this study region, we

186 therefore assume that low-temperature thermochronometric data are insensitive to heating and

187 cooling caused by migration and subduction of the Chile ridge. Instead, the apatite He

188 thermochronometric system is most sensitive to changes in erosion and topographic relief at the 
landscape surface.

190

1912.4 Glacial erosion rates in southern Chile

192 At present, there are apatite He and fission-track ages for samples from about 300 localities along

193 the $2000 \mathrm{~km}$ length of the Patagonian Andes (a limited number of locations and ages are shown in

194 Fig. 2, see Thomson et al., 2010a and Herman and Brandon, 2015 for compilation). These ages

195 collectively provide a regional framework for our understanding of glacial erosion in southern

196 Chile. Note that throughout this paper, we use the term exhumation to describe the motion of a

197 bedrock sample towards the topographic surface, and erosion to describe the removal of rock at

198 the surface. Thomson et al. (2010a) argue that samples from the northern half of the Patagonian

199 Andes saw a clear increase in exhumation rates over the last $6 \mathrm{Ma}$, whereas those from the

200 southern half saw no increase in exhumation rates. They proposed that more southern latitudes

201 should have favored cold-based glaciation, which is less erosive than warm-based glaciation

202 (Hallet et al., 1996). Using a full numerical analysis of the dataset, Herman and Brandon (2015)

203 show that, prior to 2 Ma, exhumation was everywhere slow in the Patagonian Andes, with rates of

2040.2 to $0.3 \mathrm{~km} / \mathrm{Ma}$. Since $2 \mathrm{Ma}$, a "hot spot" developed between $42^{\circ}$ to $46^{\circ} \mathrm{S}$ latitude, with 205 exhumation rates averaging 0.8 to $1.5 \mathrm{~km} / \mathrm{Ma}$. For the Patagonian Andes south of $46^{\circ} \mathrm{S}$, 206 exhumation rates remained low, at the same rate of 0.2 to $0.3 \mathrm{~km} / \mathrm{Ma}$, including the area adjacent 207 to Chile triple junction, located at $46.5^{\circ} \mathrm{S}$. We emphasize that the regional thermochronometric 208 data and the numerical solution provide only a smoothed view of the exhumation history of the 209 region. Long-wavelength features $(>\sim 100 \mathrm{~km})$ are well resolved, but local features, such as 210 glacial valleys, which were formed by locally fast erosion at the surface, are not resolved. 


\section{3. Apatite He thermochronometry}

213 Erosion at Earth's surface causes the underlying bedrock to cool as it moves upward through the

214 subsurface thermal field. Thermochronometry provides quantitative constraints on that cooling

215 history. The (U-Th-Sm)/He thermochronometric system in apatite is based on decay of isotopes

216 of U, Th, and $\mathrm{Sm}$ and the accumulation of the daughter ${ }^{4} \mathrm{He}$ inside of the apatite host crystal

217 (Farley, 2002; Ehlers and Farley, 2003). Retention of ${ }^{4} \mathrm{He}$ is controlled by thermally-activated 218 diffusion, with a closure temperature between $\sim 50-100{ }^{\circ} \mathrm{C}$ for a cooling rate of $10{ }^{\circ} \mathrm{C} / \mathrm{Ma}$ (Shuster

219 et al., 2006). The apatite He system therefore has a very shallow closure depth, $2 \mathrm{~km}$, which

220 means that it is uniquely able to measure exhumation rates over short timescales $(\sim 1 \mathrm{Ma})$ and to 221 resolve the spatial pattern of exhumation, which is essential for determining when large valleys 222 were cut.

224 Together, apatite $\mathrm{He}$ ages and ${ }^{4} \mathrm{He} /{ }^{3} \mathrm{He}$ release spectra provide two related datasets that constrain 225 cooling histories on different timescales and at different resolutions (e.g. Valla et al., 2011). An 226 apatite (U-Th-Sm)/He age ("He age") provides information on the time-temperature history, but 227 requires additional information about the cooling rate and local geothermal gradient to constrain 228 the timing of cooling through a particular temperature threshold. A suite of He ages along a 229 vertical transect shows the present spatial distribution of cooling ages as a function of elevation. 230 The age-elevation relationship is often interpreted in terms of when the individual sampled points 231 passed through the closure isotherm at depth, yielding an average exhumation rate over the time 232 interval of the oldest to youngest He age. The rate of subsequent exhumation can be estimated by 
233 the He apatite age of bedrock currently at the upper thermal boundary, approximated by the local

234 mean elevation of the landscape ("time-of-flight" in McPhillips and Brandon, 2010). For

235 example, consider a scenario with a closure depth of $\sim 2 \mathrm{~km}$ below the mean elevation and a He

236 age of $6 \mathrm{Ma}$ at the mean elevation. The sample at mean elevation moved vertically $\sim 2 \mathrm{~km}$ over

237 the interval from 6 to $0 \mathrm{Ma}$, indicating an average exhumation rate of $\sim 0.3 \mathrm{~km} / \mathrm{Ma}$ over this 238 period.

240 Apatite ${ }^{4} \mathrm{He} /{ }^{3} \mathrm{He}$ data extend the resolution of the He system to much lower temperatures, by 241 estimating the cooling history of an individual sample over the interval $\sim 80$ to $35^{\circ} \mathrm{C}$ (Shuster et 242 al., 2004; Shuster and Farley 2004, 2005). For this analysis, an apatite crystal is irradiated with $243 \sim 220 \mathrm{MeV}$ protons to produce a spatially uniform distribution of spallation ${ }^{3} \mathrm{He}$, which serves as a 244 reference for the ${ }^{4} \mathrm{He}$ analysis. Both radiogenic ${ }^{4} \mathrm{He}$ and the proton-induced ${ }^{3} \mathrm{He}$ are sequentially 245 degassed from individual apatite crystals, which initially diffuses ${ }^{4} \mathrm{He}$ from the rim, given the 246 short diffusion path, and eventually from the core, given the longer diffusion path. The measured $247{ }^{4} \mathrm{He} /{ }^{3} \mathrm{He}$ ratio release spectrum thus estimates the radial distribution of ${ }^{4} \mathrm{He}$ in the crystal that 248 resulted from open-system behavior during ${ }^{4} \mathrm{He}$ accumulation. This information can then be used 249 to constrain the sample's permissible cooling history between $\sim 80$ to $35^{\circ} \mathrm{C}$ starting at some time 250 in the past and ending at the present (Shuster et al., 2011).

\section{4. Thermochronometric data from the Patagonian fjords}

253 In this study, we collected and analyzed samples from two vertical transects in Fjord Steffen 254 (Table 1, Fig. 4) and analyzed previously collected samples (Thomson et al., 2010a) from Fjord 
255 Baker for apatite ${ }^{4} \mathrm{He} /{ }^{3} \mathrm{He}$ release spectra (locations of samples THC07 and THC08 are shown in

256 Fig. 2; results of ${ }^{4} \mathrm{He} /{ }^{3} \mathrm{He}$ analysis are shown in Fig. 5 and in the supplementary material).

257 Samples sites were selected because they are adjacent to the fjords, where valley relief is greatest.

258 Apatite $\mathrm{He}$ ages and ${ }^{4} \mathrm{He} /{ }^{3} \mathrm{He}$ release spectra were measured in the Noble Gas

259 Thermochronometry Lab of the Berkeley Geochronology Center. Well-formed, inclusion-free

260 apatite crystals were selected with a polarizing-light stereo microscope. For (U-Th-Sm)/He

261 analyses, each individual crystal was degassed by laser heating and the ${ }^{4} \mathrm{He}$ concentration was

262 measured using isotope dilution and quadrupole mass spectrometry (see Tremblay et al., 2015 for

263 analytical details). U, Th, and Sm concentrations were measured by isotope dilution using an

264 ICP-MS.

265

266 Figure 4 shows the mean, standard error, and associated young concordant crystal ages for the 267 replicated samples from Fjord Steffen (see supplementary material for full results). The apatite

268 He ages are largely clustered between 6 and 12 Ma. The two elevation transects in Fjord Steffen

269 show similar age-elevation trends (Fig 4, red and blue dashed lines), indicating fast exhumation

$270(\sim 1.0 \mathrm{~km} / \mathrm{Ma})$ from 10 to $6 \mathrm{Ma}$. The mean cooling age of the two profiles observed at the mean

271 elevation ( $\sim 8 \mathrm{Ma}$ at $\sim 600 \mathrm{~m}$ ) indicates slower exhumation, $\sim 0.3 \mathrm{~km} / \mathrm{Ma}$, from 6 to $0 \mathrm{Ma}$ (based

272 on an estimated closure depth of $2 \mathrm{~km}$ below sea level). The trend lines of the two age-elevation

273 plots are offset by 2.5 Ma. Georgieva et al. (2016) find a similar offset of He ages in two

274 vertical transects on the eastern slope of the NPI, which they attribute to differential tectonic

275 uplift, post-dating the closure of the apatite He system of the youngest samples. There are no

276 observed faults separating the transects in Fjord Steffen, or other evidence of young tectonic

277 motion in the local area. Another possibility is that the offset in mean ages and ages of samples at 
278 similar elevations is due to lateral incision or headward erosion of the valley, resulting in the 279 northern profile cooling more recently (e.g. Shuster et al., 2011).

281 Figure 5 shows the observed ${ }^{4} \mathrm{He} /{ }^{3} \mathrm{He}$ ratios as a function of total ${ }^{3} \mathrm{He}$ abundance (black outlines) 282 for two samples collected at sea level along the west end of Fjord Baker (see locations in Fig. 2).

283 Six other small apatite crystals were analyzed for ${ }^{4} \mathrm{He} /{ }^{3} \mathrm{He}$ ratios. Although the data are internally 284 consistent (Table S3), those smaller crystals did not have sufficient helium content for precise $285{ }^{4} \mathrm{He} /{ }^{3} \mathrm{He}$ analyses. Therefore, our cooling history estimates are based on the remaining two 286 samples, which did have sufficient He. The apatite $\mathrm{He}$ analyses of the two samples were 287 previously reported in Thomson et al. (2010a). Sample THC07 (Fig. 5a; Table S3 THC07a) has a 288 He age of $9.17 \pm 0.22 \mathrm{Ma}$. The ${ }^{4} \mathrm{He} /{ }^{3} \mathrm{He}$ data for an individual apatite crystal from this sample 289 indicates cooling at a rate of $\sim 15^{\circ} \mathrm{C} / \mathrm{Ma}$ between the interval of 10 to $5 \mathrm{Ma}$ (best-fit solutions 290 shown are green paths in Fig. 5). Sample THC08 (Fig. 5b; Table S3 THC08b) has a He age of $2916.43 \pm 0.15 \mathrm{Ma}$ and ${ }^{4} \mathrm{He} /{ }^{3} \mathrm{He}$ data that indicate a cooling rate of $>30{ }^{\circ} \mathrm{C} / \mathrm{Ma}$ at $\sim 7$ to $5 \mathrm{Ma}$. Both 292 results indicate that the samples were at or near the surface $\left(<35^{\circ} \mathrm{C}\right)$ by $5 \mathrm{Ma}$.

\section{5. Modeling cooling ages and rates}

295 Conventional apatite He analysis provides only an age, with no direct information about 296 temperature at that time. The usual practice is to use thermal modeling and the closure model of 297 Dodson $(1973 ; 1979)$ to calculate an effective closure temperature, which crudely provides one 298 point on the time-temperature cooling history of an apatite crystal and its corresponding rock 299 sample. In contrast, the ${ }^{4} \mathrm{He} /{ }^{3} \mathrm{He}$ method provides an estimate of temperature as a function of 
300 time.

301

302 We define two parameters, $\tau_{65}$ and $\gamma_{80-35}$, to summarize the cooling history as estimated by the

$303{ }^{4} \mathrm{He} /{ }^{3} \mathrm{He}$ method. The parameter $\tau_{65}$ indicates the time that the sample cooled through $65^{\circ} \mathrm{C}$. The 304 parameter $\gamma_{80-35}$ is an estimate of the average cooling rate over the interval 80 to $35^{\circ} \mathrm{C}$. The 305 variables can be viewed as a straight-line approximation for the age-temperature path, with a 306 point located in the center of the path, at $65{ }^{\circ} \mathrm{C}$ and age $\tau_{65}$, and the slope of the cooling path 307 given by $\gamma_{80-35}$. We chose the temperature $65^{\circ} \mathrm{C}$ as the midpoint because it is commonly cited as

308 the nominal closure temperature for conventional He apatite analysis, assuming a typical orogenic 309 cooling rate of $10^{\circ} \mathrm{C} / \mathrm{Ma}$ (Shuster et al., 2006). Figure 6 shows a simple example of modeled $\tau_{65}$ 310 and $\gamma_{80-35}$ values for a vertical suite of samples along the wall of Fjord Messier.

312 Much work has been done to relate thermochronometry to changes in surface topography using 313 numerical modeling (e.g. Braun, 2003; Ehlers and Farley 2003; Ehlers et al., 2006; Braun et al., 314 2012). The most common approach is to use the PECUBE program to predict the pattern of 315 thermochronometric ages as a function of a specified history of uplift, erosion, and surface 316 topography. Our approach differs in three ways. The first is that we use a new formulation for the 317 evolution of surface topography. The second is that we use a Fourier-based numerical method 318 that allows us to separate the two-dimensional evolution of the topographic surface from the more 319 one-dimensional evolution of the thermal structure in the underlying crust as a function of a 320 regionally average erosion rate. This methodology was first introduced in Thomson et al. 321 (2010b). The results are equivalent to those provided by PECUBE, but the calculations are much 
322 faster, which allows for a more complete exploration of parameter space. The third difference is 323 that we focus on how various erosion and relief scenarios influence the spatial distributions for $324 \tau_{65}$ and $\gamma_{80-35}$, as rendered in map view.

\subsection{Topography parameterization}

327 Topographic scenarios are constructed using a decomposed version of the modern topography.

328 Our approach is based on the idea that tectonic uplift produces long-wavelength topography, and 329 erosion reduces the high points of that tectonic topography and also creates incised features like 330 valleys, due to localized erosion by rivers or glaciers. Thus, the tectonic topography can be 331 approximated by a smoothed "draped" surface that touches only the highest summits. Consider 332 the observed topography as represented by gridded elevations, designated by the matrix $H$. The 333 matrix $S$ represents the gridded summit topography. We estimate the summit topography using an 334 asymmetric least-squares smoothing routine. This estimate was done using an algorithm that fits a 335 smooth surface to an arbitrary set of 2D values (Garcia, 2010). The fit is asymmetrically weighted 336 (Eilers and Boelens, 2005) to favor the highest points in the landscape, which gives a robust 337 estimate of a smoothed draped surface resting on the highest summits. Given the summit valley, $338 S$, we can define a second component of the landscape, which is the valley relief, $V=S-H$.

340 The topography decomposition is the basis for describing candidate solutions for past 341 topographies. We view candidate topographies, $H_{c}$, as approximated by a scaled linear 342 combination of the summit and valley components of the modern topography, as indicated by $H_{c}$ $343=f_{v} V+f_{s} S$. The two parameters, $f_{v}$ and $f_{s}$, provide a simple representation of a wide range of 
344 plausible topographies. For example, $f_{v}=f_{s}=1$ represents the modern topography. Braun (2003)

345 uses a similar approach for his PECUBE program. There the candidate topographies are defined

346 by $H_{\mathrm{c}}=f_{a} H+f_{o}$, where the parameters, $f_{a}$ and $f_{o}$, are amplification and offset factors, respectively.

349 We use a two-component thermal model for estimating the depth and thermal gradient associated 350 with the $35,65,80^{\circ} \mathrm{C}$ isotherms. The first component is a one-dimensional regional thermal field 351 defined by an infinite layer with horizontal upper and lower surfaces. The upper surface is fixed 352 at the mean elevation and the lower surface at $30 \mathrm{~km}$ below the mean elevation. The second 353 component represents the influence of topography on the underlying thermal field in three 354 dimensions, which is calculated using a third-order Fourier-series solution (Fyrillas and

355 Pozrikidis, 2001). We use thermal parameters specific to our study region, including a thermal 356 diffusivity of $32 \mathrm{~km}^{2} / \mathrm{Ma}\left(\sim 1 \mathrm{~mm}^{2} / \mathrm{s}\right)$, and a regional erosion rate of $0.25 \mathrm{~km} / \mathrm{Ma}$ (Thomson et al., 357 2010a; Herman and Brandon, 2015). The internal heat production has little effect for this 358 problem, and is thus set to zero. The temperature at the mean elevation is set to $0{ }^{\circ} \mathrm{C}$, which is 359 consistent with the expected long-term temperature of the atmosphere at that elevation. The 360 temperature at the base of the model is set to $750{ }^{\circ} \mathrm{C}$, which gives an average geothermal gradient 361 of $\sim 25^{\circ} \mathrm{C} / \mathrm{km}$ and a surface heat flow consistent with modern measurements (Hamza et al., 362 2005). The surface topography is overlain by air above sea level and water below sea level. The 363 surface boundary is dominated by the submarine part of the topography. The water column has 364 little to no thermal gradient, so we set the surface lapse rate of the model to $0{ }^{\circ} \mathrm{C} / \mathrm{km}$. 
366 The examples used here are focused on the influence of changes in topography on $\tau_{65}$ and $\gamma_{80-35}$,

367 and by extension, observed apatite $\mathrm{He}$ ages and ${ }^{4} \mathrm{He} /{ }^{3} \mathrm{He}$ data. For this purpose, the regional 368 erosion rate is held at constant value, which means that the one-dimensional regional thermal

369 structure remains steady. The shallow thermal structure adjusts quickly to changes in valley 370 topography ( $\sim .1 \mathrm{Ma}$ response time) given the short distance between the 35 to $80{ }^{\circ} \mathrm{C}$ isotherms 371 and the surface boundary (Stüwe and Hintermüller, 2000). As a result, the time lag between 372 valley incision and the response of the 35 to $80{ }^{\circ} \mathrm{C}$ isotherms can be ignored. Thus, we can 373 assume a quasi-steady relationship between the surface boundary condition and the shallow 374 isotherms.

376 Our approach allows for a decoupled analysis of the evolution of summit topography and valley 377 relief, as applied to morphological evolution of the topography and also to the evolution of the 378 shallow thermal field beneath the topography. The summit topography is mainly created by 379 tectonic processes operating at the regional scale, whereas the valley topography is mainly 380 created by incision by rivers and glaciers. Thus, our topographic parameterization emphasizes the 381 evolution of summit topography, as controlled by tectonic uplift and an average erosion rate at a 382 regional scale, and by valley incision, which can be viewed as variations in erosion at a local 383 scale. The thermal modeling is likewise decoupled in a similar way. The 1D component of the 384 thermal model represents the thermal evolution at a regional scale as a function of the regional 385 erosion rate, which is recorded by our cooling ages as a regional exhumation rate. The 386 topographic component of the thermal model accounts for the evolution of the thermal field as a 387 function of changing valley relief. These two components can be calculated separately, which 388 allows for an easier understanding about how regional erosion and valley relief influence cooling 
ages.

390

\subsection{Map view prediction of cooling ages and rates}

392 Bedrock cooling ages are simply the intersection of isochrones with modern topography. To

393 calculate $\tau_{65}$ values for the modern bedrock surface, we approximate the 3-dimensional shape of 394 the $65^{\circ} \mathrm{C}$ isotherm through time (as prescribed by a topographic scenario outlined in section 6.1) 395 and advect it vertically at the regional exhumation rate $(0.25 \mathrm{~km} / \mathrm{Ma})$. For example, the $6 \mathrm{Ma}$ 396 isochrone represents the shape of the $65^{\circ} \mathrm{C}$ isotherm at $6 \mathrm{Ma}$. Given the regional exhumation rate, 397 this isochrone should currently be at a vertical height of $1.5 \mathrm{~km}$ above the modern $65^{\circ} \mathrm{C}$ isotherm.

399 To model average cooling rates between 80 and $35{ }^{\circ} \mathrm{C}, \gamma_{80-35}$, the 3 -dimensional shape of the 80 400 and $35{ }^{\circ} \mathrm{C}$ isotherms through time are advected at the regional exhumation rate. Therefore, each 401 point at the surface has two additional "cooling ages", $\tau_{80}$ and $\tau_{35}$ that indicate the time since 402 passing through the 80 , and $35{ }^{\circ} \mathrm{C}$ isotherms, respectively. The cooling rate is equivalent to the 403 difference in temperature, divided by the difference in age: $\left(80-35^{\circ} \mathrm{C}\right) /\left(\tau_{80}-\tau_{35}\right)$.

\section{6. Thermochronometric signals for topographic evolution}

\section{6.1 Modeled valley incision scenarios}

407 We consider several hypotheses that illustrate how thermochronometric results vary as a function 408 of different topographic scenarios (Fig. 7). Each of the hypotheses described below was chosen to 409 highlight the connection between specific thermochronometric outcomes and a broader topical 
410 issue.

411

412 Steady-state: For this reference hypothesis, topography maintains a constant form with time,

413 which requires the exhumation rate to be spatially uniform. In practical terms, this scenario

414 describes an "antecedent landscape", which means that the shape of the topography was formed

415 prior to the onset of glaciation. This possibility is unlikely in Patagonia, given the fact that the

416 modern landscape is laced with kilometer-deep fjords, but it provides a useful reference for the

417 following alternative hypotheses.

418

419 Early Incision: Valley relief is created rapidly after the onset of mountain glaciation. This

420 scenario is motivated by the presence of glacial till dating to $\sim 7$ to $5 \mathrm{Ma}$ (Mercer et al., 1982;

421 Ton-That et al., 1999) and follows the widely held view that glaciers are more erosive than rivers

422 (see discussions in Hallet et al. 1996; Brocklehurst and Whipple, 2004; Koppes and Montgomery,

423 2009; Yanites and Ehlers, 2012).

425 Steady Incision: Valley relief is formed at an approximately steady rate. This scenario is based on 426 the idea of a negative feedback between glacial erosion and topography (Oerlemans, 1984;

427 MacGregor et al., 2000; Kaplan et al., 2009; Shuster et al., 2011). Glacial erosion tends to reduce

428 the ice catchment (accumulation zone) required to feed the glacier. As a result, the rate of glacial 429 erosion is linked to the long-term evolution of the ELA. Late Cenozoic cooling has caused a long430 term lowering of the ELA in temperate latitudes. The idea is that valley incision would proceed at 431 a similar rate. 
433 Late Incision: Valley relief formed recently $(<\sim 2 \mathrm{Ma})$. This scenario is motivated by two previous

$434{ }^{4} \mathrm{He} /{ }^{3} \mathrm{He}$ apatite studies in mountain landscapes elsewhere that show an onset of rapid glacial

435 incision at $\sim 1 \mathrm{Ma}$ (Shuster et al., 2011; Valla et al., 2011). Timing might be related to the mid-

436 Pleistocene transition (1.2 to $0.7 \mathrm{Ma}$ ), when glacial-interglacial cycle changed from a period of 41

437 ka to $100 \mathrm{ka}$ (e.g. Pedersen and Egholm, 2013). A similar timing in southern Chile would be 438 interesting, given that glaciations there started much earlier, by at least $\sim 7$ to $5 \mathrm{Ma}$, than in most 439 other alpine glaciated settings (e.g. 2.6 Ma in the European Alps; Preusser et al., 2012).

\section{$441 \quad 6.2$ Cooling age and rate model results}

442 The results of the model are summarized in Figure 7. Column 1 provides an expanded view of the 443 predictions for the Steady-state case relative to Figure 6. Bedrock in the summit regions are 444 distinguished by old cooling ages $(\sim 15 \mathrm{Ma})$ and low cooling rates $\left(\sim 5^{\circ} \mathrm{C} / \mathrm{Ma}\right)$. Valleys have 445 intermediate ages ( 8 to $10 \mathrm{Ma})$ and low cooling rates $\left(\sim 7^{\circ} \mathrm{C} / \mathrm{Ma}\right)$. The deeply incised fjords have 446 young ages ( $\sim 6 \mathrm{Ma})$ and moderate cooling rates $\left(\sim 8\right.$ to $\left.12^{\circ} \mathrm{C} / \mathrm{Ma}\right)$. The predicted cooling ages are 447 primarily a function of elevation above the closure surface. Predicted ages are younger at low 448 elevation and older at high elevations. Note that all of the scenarios predict faster cooling beneath 449 fjords relative to summits because near-surface isotherms are always compressed beneath the 450 valleys and expanded beneath summits (e.g., Fig. 6).

452 The alternative hypotheses (Fig. 7, Columns 2-4) highlight the ability of low-temperature 453 thermochronometric data to resolve the timing and rates associated with changes in relief. These 
454 models each predict identical He ages and cooling rates $\left(\tau_{65}\right.$ and $\left.\gamma_{80-35}\right)$ in summit regions because

455 the forward models are initiated with the same steady-state, low-relief topography from 15 to 7

456 Ma. The thermochronometric predictions for the alternative hypotheses begin to diverge at 7 Ma.

457 This difference is recorded in modern bedrock exposures at $\sim 0 \mathrm{~m}$ elevation and varies based on 458 the local depth to the $65^{\circ} \mathrm{C}$ isotherm. The largest difference in cooling ages between the modeled 459 scenarios is at the lowest elevations in the landscape, which is the bottom of the fjords. Our 460 observations are limited to where we can sample, at elevations between 0 to $1200 \mathrm{~m}$ (Fig. 2). The 461 calculations shows that while there are slight differences in predicted He ages for end-member 462 topographic scenarios at 0 to $1200 \mathrm{~m}$, these differences are within the uncertainty for the ages, 463 which is typically $\sim 10 \%$ (Farley et al., 2002). Thus, He ages from subaerial outcrops are unable 464 to distinguishing between the competing topographic scenarios.

$466{ }^{4} \mathrm{He} /{ }^{3} \mathrm{He}$ thermochronometry provides a way forward. In the Early Incision scenario (Fig. 7, 467 Column 2), the model predicts relatively rapid cooling (high cooling rates) in the valleys and 468 fjords. The Early Incision scenario illustrates fast erosion of the valleys from 7 to 5 Ma, which 469 results in fast cooling there from 7 to 5 Ma. The Steady Incision scenario (Fig. 7, Column 3) 470 illustrates the prediction for a landscape in which the valley depth increases gradually over time. 471 In this scenario, erosion of the valleys and fjords proceeds at a greater rate than erosion in the 472 upland regions. As a result, the fjords show faster cooling relative to the upland areas over the last $4737 \mathrm{Ma}$. The Late Incision scenario postulates that the valley relief formed during the last $2 \mathrm{Ma}$. In 474 this scenario, the model predicts that the fjords would be floored by young cooling ages of $\sim 1-2$ 475 Ma with high cooling rates. In contrast, the upper parts of the valley (presently above sea level) 476 and the upland areas would have cooling ages older than $\sim 6 \mathrm{Ma}$ and lower cooling rates. 


\section{Discussion}

479

\subsection{Comparison of model results and data}

480 The map-based predictions of cooling ages and rates allow us to directly compare the spatial 481 pattern of the $\mathrm{He}$ ages and ${ }^{4} \mathrm{He} /{ }^{3} \mathrm{He}$ data resulting from different topographic scenarios (Fig. 7). 482 Here we compare the four models to the key constraints in our data: The He ages from the Fjord 483 Steffen transects (Table 1) and the exhumation rate estimates derived from the age-elevation plot 484 (Fig. 4), and the cooling history information from the sea level samples along Fjord Baker (Fig. $485 \quad 5)$

487 The observed He ages, which range from 5.8 to 11.3 Ma (Table 1), do not constrain the 488 topographic history because the scenarios predict similar modeled He ages within the available 489 sampling range, between 0 to $1200 \mathrm{~m}$ elevation. The time-of-flight exhumation rate of $\sim 0.3$ $490 \mathrm{~km} / \mathrm{Ma}$ fails to resolve any change in exhumation rate associated with glacial erosion that might 491 have happened since $\sim 8 \mathrm{Ma}$ because the time-of-flight exhumation rate is averaged over the 492 interval of $8 \mathrm{Ma}$ to the present.

493

494 The individual cooling histories of the two samples from Fjord Baker (Fig. 5) are needed to 495 resolve changes in exhumation rate since $8 \mathrm{Ma}$. Both ${ }^{4} \mathrm{He} /{ }^{3} \mathrm{He}$ release spectra indicate that the 496 samples cooled rapidly from high temperatures $\left(>85^{\circ} \mathrm{C}\right)$, through the closure temperature and 497 below $35^{\circ} \mathrm{C}$ between 10 and 5 Ma. The Early Incision landscape evolution model (Row 2 in Fig. 
498 7), where incision occurred rapidly between 7 to $5 \mathrm{Ma}$, is the only scenario in which samples

499 currently at subaerial locations have estimated fast cooling rates. We therefore conclude that the 500 results of early rapid cooling at a rate of $15-30{ }^{\circ} \mathrm{C} / \mathrm{Ma}$ between 10 to $5 \mathrm{Ma}$ show that early 501 glaciations in central Patagonia rapidly eroded valleys into the landscape, and the modern 502 observed valley relief was formed by $\sim 5$ Ma.

503

504 Others have proposed tectonic and geodynamic interpretations for evolution of topography in this 505 region (e.g., Cande and Leslie, 1986; Ramos and Ghiglione, 2008; Guillaume et al., 2013; Braun 506 et al., 2013; Georgieva et al., 2016). He age data from this study reveal a fast exhumation rate 507 between $\sim 0.5$ to $1 \mathrm{~km} / \mathrm{Ma}$ from 10 to $6 \mathrm{Ma}$. Guillaume et al. (2013) report a similar trend in He 508 age with elevation in both the Cerros Barrancos region, $75 \mathrm{~km}$ east of Fjord Steffen, and farther 509 northeast along the margin of Lago General Carrera. They find apatite He ages between 5 and 10 510 Ma that indicate exhumation rates of $\sim 0.5 \mathrm{~km} / \mathrm{Ma}$ over this duration. Georgieva et al. (2016) find 511 a similar trend in He ages in vertical transects in glacial valleys east of the NPI. Farther afield, a 512 study in the southern Andes $\left(\sim 51^{\circ} \mathrm{S}\right)$, finds young apatite He ages $(<10 \mathrm{Ma})$ that are interpreted as 513 a record of glacial erosion starting at $\sim 7 \mathrm{Ma}$ (Fosdick et al., 2013). Importantly, we show that 514 these thermochronometric datasets can be explained entirely by rapid increase in valley relief 515 between $\sim 10$ to $5 \mathrm{Ma}$. This is in contrast to the interpretation of Guillaume et al. (2013), which 516 attributes the observed cooling to dynamic topography associated with the slab window.

518 The topography around the Patagonian fjords between 47.5 and $48.5^{\circ} \mathrm{S}$ has both a lower mean 519 elevation and lower summit elevations than the topography to the north and south (the regions 
520 currently covered by the NPI and SPI). Georgieva et al. (2016) attribute the anomalously low

521 elevation of this region to margin-parallel extension related to the subduction of ridge segments at

522 the Chile triple junction since 2-3 Ma. Lowering the mean topographic elevation in this region

523 could occur by block subsidence, erosion of the surface, or a combination of the two. While our

524 data are technically consistent with block subsidence since 2-3 Ma, there is no independent

525 evidence for a block subsidence scenario. Our thermochronometric data do preclude large-scale

526 erosion of the topography since $5 \mathrm{Ma}$. Erosion of the surface causes rocks to be exhumed towards

527 the Earth's surface. Because the upper crustal thermal field is coupled to the surface boundary

528 condition, a large-scale erosional event lowering the topographic surface would be captured in the

529 low-temperature thermochronometric data. The ${ }^{4} \mathrm{He} /{ }^{3} \mathrm{He}$ cooling histories from this area show

530 that the bedrock cooled to surface temperatures by $5 \mathrm{Ma}$, indicating very slow exhumation and

531 therefore minor erosion of the topography since $5 \mathrm{Ma}$.

532

533 Given that the thermochronometric data can be explained entirely by a regional exhumation rate 534 of $0.25 \mathrm{~km} / \mathrm{Ma}$ with an increase in valley relief at $\sim 7 \mathrm{Ma}$, along with the lack of structural 535 evidence for modification by tectonics in the fjords, and the results of modeling the upper crustal 536 temperature above the ridge subduction (Fig. 3) which shows a negligible effect of Chile triple 537 junction on the upper crustal thermal field, we prefer a glacial erosion model for the central 538 Patagonian Andes. The primary topographic change in our study area was the punctuated incision 539 of valleys and fjords soon after the onset of glaciation. Early glaciations caused rapid erosion of 540 the fjords in our study area until $\sim 5 \mathrm{Ma}$, when samples that are currently at sea level exhumed to 541 temperatures less than $\sim 35^{\circ} \mathrm{C}$. Neotectonic activity, recognized by Georgieva et al. (2016) on the 542 eastern flank of the NPI, and thought to be active since $\sim 2-3 \mathrm{Ma}$, are not resolved by our 
543 thermochronometric data or in our thermal-kinetic model. However, our data do require slow

544 erosion and therefore little topographic change in the fjords since $\sim 5 \mathrm{Ma}$.

545

$546 \quad 7.2$ Thermochronometric signatures of the timing of valley incision

547 The thermal-kinetic model gives a map view of the thermochronometric signature of valley relief

548 formation scenarios (Fig. 7). While the model results presented in this paper are specific to

549 Patagonia, the method provides insight into the valley incision problem in general and the

550 resolution of low-temperature thermochronometric data. The modeled cooling information shows

551 how the spatial patterns of He ages and cooling rates $\left(\tau_{65}\right.$ and $\left.\gamma_{80-35}\right)$ constrain landscape evolution.

552 Specifically, Figure 7 show that ${ }^{4} \mathrm{He} /{ }^{3} \mathrm{He}$ is needed to resolve valley incision and that there are 553 predictable patterns of thermochronometric cooling data for given landscape evolution scenarios.

555 To further illustrate this concept, consider another example from the upper Rhône Valley in the

556 Swiss Alps (Fig. 8; Valla et al., 2011). Apatite He ages from an elevation traverse in the upper

557 Rhône Valley increase monotonically from 4 to $8 \mathrm{Ma}$, with increasing elevation (Fig. 8b). The

558 elevation-age gradient, $\sim 0.6 \mathrm{~km} / \mathrm{Ma}$, estimates the exhumation rate from 8 to $4 \mathrm{Ma}$ and the He

559 age at the current mean elevation indicates an average exhumation rate of $\sim 0.3 \mathrm{~km} / \mathrm{Ma}$ over the

560 interval from 6 to 0 Ma. As with our He age results from Patagonia, the He ages alone fail to

561 resolve any change in exhumation rate associated with glacial erosion, which started at 2.6 Ma in

562 the Alps (Preusser et al., 2012). ${ }^{4} \mathrm{He} /{ }^{3} \mathrm{He}$ thermochronometry is needed to adequately resolve the

563 exhumation history during this younger interval. In the Alps, a valley-bottom sample (Fig. 8e,

564 SIO-04) experienced fast cooling starting at $\sim 1 \mathrm{Ma}$, while a high-elevation sample (Fig. 8c, SIO- 
565 06) was near the Earth's surface by $\sim 2.5 \mathrm{Ma}$, indicating that the cooling was related to an increase

566 of valley relief of $\sim 1 \mathrm{~km}$ (i.e., the difference in elevation of the samples).

567

568 The Rhone Valley data provide a characteristic example of a young valley incision event, where

569 formation of the valley relief postdates the bedrock apatite He ages observed at the surface. In

570 contrast, the observed He data in Patagonia, as illustrated in Early Incision landscape evolution

571 model (Row 2 in Fig. 7), show a characteristic example in which the formation of valley relief

572 coincides with the timing of the closure of the He system. A third end-member scenario,

573 illustrated by the Steady state case in Figure 7 Row A, shows the thermochronometric signature

574 of an old incision event, where the formation of valley topography pre-dates the closure of the

575 samples currently at the surface. In each case, the thermochronometric signature is distinct timing

576 of cooling in bedrock at different vertical positions and only a small number of samples are

577 needed to resolve the timing of valley formation.

578

579 Finally, our results also highlight the importance of the regional exhumation rate in controlling

580 the thermochronometric record. A common strategy in thermochronometric studies is to sample

581 over a large vertical range to ensure a long record of cooling ages. However, the duration of that

582 record is a function of both the vertical sampling range and the regional exhumation rate. The

583 regional exhumation rate in central Patagonia is relatively low, $\sim 0.25 \mathrm{~km} / \mathrm{Ma}$, which means that

584 there is a large range of cooling ages in the vertical. This feature is like a condensed stratigraphic

585 section, which is characterized by a long time range in a short section. ${ }^{4} \mathrm{He} /{ }^{3} \mathrm{He}$

586 thermochronometry is especially useful in this setting in that we are provided with a long record 
587 of very-low temperature cooling. To illustrate, consider the Steady and Late Incision scenarios, 588 where fast cooling would only be observed in bedrock surfaces currently below sea level. In 589 contrast, consider the thermochronometric record of glacial incision in Fiordland, New Zealand, 590 where the regional exhumation rate is four times faster (Shuster et al., 2011). This scenario, 591 which is not illustrated in Fig. 7, has very young cooling ages in all areas including the highest 592 summits. For Fiordland, the subaerial topography, which reaches $\sim 1.5 \mathrm{~km}$ above sea level, has 593 only a short range of cooling ages, spanning $\sim 1$ to $2 \mathrm{Ma}$. This case is analogous to an expanded 594 stratigraphic section, where the age range is unexpectedly small. The important point is the 595 apatite He ages cannot provide any information about the formation of that landscape prior to 2 596 Ma. However, the subaerial bedrock in that area preserves an excellent record of the young 597 evolution of that glacial landscape (Shuster et al., 2011).

\subsection{Implications for understanding of glacial erosion}

600 Much of the debate about long-term results of glacial erosion has focused on how glaciers have 601 resculpted the tops of mountains, by lowering summits or enlarging cirques (Porter, 1989; 602 Brocklehurst and Whipple, 2004; Oskin and Burbank, 2005; Egholm et al., 2009). Our work here 603 focuses on the lowest parts of the glacial landscape, which are ubiquitous in continental regions at 604 high latitudes around the globe. We find evidence for two interesting conclusions: 1) that valley 605 incision has dominated much of the topographic evolution of the central Patagonian Andes, and 606 2) that the cutting of those valleys occurred shortly after the start of alpine glaciations. What is 607 surprising is how slow erosion has been since $5 \mathrm{Ma}$. To emphasize this point, consider that our 608 sea level samples have been at temperatures less than $35^{\circ} \mathrm{C}$ since $5 \mathrm{Ma}$, indicating erosion rates 
609 of $<0.2 \mathrm{~km} / \mathrm{Ma}$. This conclusion is perhaps expected given our current understanding of glacial

610 erosion. The first is the negative feedback between glaciation and erosion; As glaciation

611 progresses, elevation of the upstream accumulation zone is gradually eroded (Oerlemans, 1984).

612 In other words, glaciers tend to cannibalize their ice catchment, leading to a decrease in ice

613 discharge and erosion at some time after the start of alpine glaciations. A second related effect is

614 that the lowering of bedrock by erosion results in thicker ice during subsequent glaciations.

615 Thicker ice should have lower basal sliding velocities, assuming that the ice discharge remains

616 the same. A third effect is that Late Cenozoic cooling leads to an increase of cold-based ice. All

617 of these factors would lead to a reduction in glacial erosion rates with time.

618

619 Our results also have implications for our understanding of the feedbacks between global climate 620 and timing of glacial erosion. The Central Patagonian Andes have a record of early alpine 621 glaciations, and our work now demonstrates an early history of valley incision, both prior to $\sim 5$ 622 Ma. These results are in stark contrast to other mid-latitude settings, especially in the northern 623 hemisphere, where alpine glaciations started in the early Pleistocene (e.g., $2.6 \mathrm{Ma}$ in the Alps;

624 Preusser et al., 2012). There has been much discussion about the possibility that the mid625 Pleistocene glacial transition (1.2 to $0.7 \mathrm{Ma}$; Berger et al., 2008) may have marked a time of 626 increased glacial incision around the world (Valla et al., 2011; Herman et al., 2013; Pedersen and 627 Egholm, 2013). Based on our work, we see an equally viable interpretation that rapid valley 628 incision is associated with the onset of alpine glaciations. This alternative explanation explains 629 the observed fast incision in Patagonia soon after the first known glaciations and other mid630 latitude settings where the timing of the onset of glaciation is known. We leave open the 631 possibility that global climate change influences glacial erosion rates in Patagonia and elsewhere. 
632 The results presented in this paper do not resolve erosional events younger than $\sim 5 \mathrm{Ma}$. Patagonia 633 is an interesting location to explore the influence of the mid-Pleistocene glacial transition, 634 especially given the depth of the fjords, which we show in our model may contain a 635 thermochronometric record of young erosional events in bedrock beneath sea level.

\section{8. Conclusions}

638 In this study, we illustrate how low-temperature thermochronometry can constrain the timing of 639 glacial valley incision in Patagonia. Our thermal-kinetic modeling results show the resolution of 640 apatite $\mathrm{He}$ data and the distinct thermochronometric signatures for different topographic 641 scenarios. Apatite $\mathrm{He}$ ages and ${ }^{4} \mathrm{He} /{ }^{3} \mathrm{He}$ thermochronometry from southern Chile require rapid

642 cooling between 10 to $5 \mathrm{Ma}$. We show that migration of the Chile triple junction had a negligible 643 influence on the thermal structure of the shallow crust in the Patagonian forearc. Therefore, we 644 conclude the thermochronometric signal of fast cooling is likely due to an increase in valley relief 645 coinciding with early glaciations in the Andes. Erosion rates in the trunk valleys far outpaced 646 erosion in the summits or hanging valleys and valley incision proceeded rapidly. Samples 647 currently at sea level were near the surface by $\sim 5 \mathrm{Ma}$. These results suggest that the primary 648 topographic effect of glacial erosion is the incision of valleys and fjords soon after the onset of 649 glaciation.

\section{Acknowledgements}

652 We would like to thank Stuart Thomson for providing samples for apatite ${ }^{4} \mathrm{He} /{ }^{3} \mathrm{He}$ analysis, 653 Wendy DeWolf and Ryan Laemel for their help collecting and processing samples, and Nick 
654 Fylstra for laboratory assistance. Fieldwork was only possible given the logistical support 655 provided by Noel Vidal and Maria Paz Hargreaves (Entre Hielos, Caleta Tortel). We would also 656 like to thank Keith Ma for many discussions about the glacial history of Patagonia that inspired 657 this work. Eva Enkelmann and an anonymous reviewer provided thoughtful comments that 658 improved the manuscript. Christeleit acknowledges support from a NSF Graduate Research 659 Fellowship, Yale University, and the Yale Institute for Biospheric Studies. Shuster acknowledges 660 the support of the Ann and Gordon Getty Foundation.

661

\section{Figure Captions}

663 Figure 1. Figure 1. Map of Patagonia with extent of modern and Last Glacial Maximum (LGM, $66420 \mathrm{ka}$ ) glaciations, and the Greatest Patagonian Glaciation (GPG, 1.2 to $1.0 \mathrm{Ma}$ ). The yellow 665 stars show the location of older glacial deposits ( $\sim 6 \mathrm{Ma}$ and $3.4 \mathrm{Ma}$ ). The Cretaceous-Paleogene 666 Patagonian Batholith (pink) underlies the core Patagonian Andes. The Nazca, South American, 667 and Antarctic plates meet at the Chile triple junction, located at $\sim 46.5^{\circ} \mathrm{S}$. The circles and ages 668 show the migration path of the triple junction along the Chile trench (Breitsprecher and 669 Thorkelson, 2009).

670

671 Figure 2. Topography and bathymetry of our study area with existing and new apatite He ages 672 (our study; Thomson et al., 2010a; Guillaume et al., 2013; Georgieva et al., 2016). Our study 673 provides new He apatite cooling ages from two vertical transects in Fjord Steffen and two $674{ }^{4} \mathrm{He} /{ }^{3} \mathrm{He}$ analyses from Fjord Baker. Grid resolution for elevation and bathymetry is better than $675925 \mathrm{~m}$ grid spacing (SRTM30 Plus v6.0).

676 
677 Figure 3. One-dimensional model of the thermal influence of the passage of the Chile triple

678 junction beneath our study area over the last $20 \mathrm{Ma}$. The vertical temperature profile was

679 calculated $100 \mathrm{~km}$ inland from the Chile trench at $47.5^{\circ} \mathrm{S}$. (a) Simplified representation of the

680 subduction zone. $V_{f}$ is the downgoing plate velocity, and $z_{f}$ is the local depth to the subduction

681 thrust. (b) Model inputs: plate age $t_{o}$ at the trench at $47.5^{\circ} \mathrm{S}$ from 20 to $0 \mathrm{Ma}$ (Cande and Leslie,

682 1986); subduction velocity $V_{f}$ through time; temperature at $z_{f}$ on the subduction thrust from 20 to

$6830 \mathrm{Ma}$. Prior to $10 \mathrm{Ma}$, the Nazca plate was subducted at a trench orthogonal rate of $>100 \mathrm{~km} / \mathrm{Ma}$.

684 The age of the subducted oceanic lithosphere became progressively younger until the Antarctic-

685 Nazca spreading ridge was subducted from 10-8 Ma (Cande and Leslie, 1986; Breitsprecher and

686 Thorkelson, 2009). Since $8 \mathrm{Ma}$, the Antarctic plate has been subducted at an orthogonal rate of

$687 \sim 20 \mathrm{~km} / \mathrm{Ma}$ (Breitsprecher and Thorkelson, 2009). (c) Vertical temperature profile through time.

688 The inset shows the modeled temperature at a depth of 1, 3, and $5 \mathrm{~km}$ from 20 to $0 \mathrm{Ma}$.

689

690 Figure 4. Vertical transects at Fjord Steffen. (a) Topography and bedrock sample locations for

691 vertical transects and distribution of samples in profiles across the fjord. (b) Age-elevation plot

692 for He apatite ages. Black points are individual crystal ages, diamonds and horizontal lines are

693 unweighted mean ages and standard error, respectively. Dashed blue lines show the local trend of

694 the He cooling ages as a function of elevation. Dashed black line shows the time-of-flight trend as

695 calculated using the approximate age at the mean elevation $(600 \mathrm{~m})$ of the local topography and

696 the estimated depth of the closure temperature at $2 \mathrm{~km}$ below sea level. Together, these trends

697 indicate fast cooling from 10 to $6 \mathrm{Ma}$ and slower cooling from 8 to $0 \mathrm{Ma}$.

698 
699 Figure $5^{4} \mathrm{He} /{ }^{3} \mathrm{He}$ thermochronometry and estimated cooling paths (see Fig. 2 for sample

700 locations). In the left panels, $R_{\text {step }}$ is the ${ }^{4} \mathrm{He} /{ }^{3} \mathrm{He}$ ratio observed at each degassing step, $R_{\text {bulk }}$ is

701 determined by summing all steps, and $\sum \mathrm{F}^{3} \mathrm{He}$ is the cumulative release fraction of ${ }^{3} \mathrm{He}$. Open

702 black boxes indicate 1 standard error (vertical) and integration steps (horizontal). In the right

703 panels, the colored lines show randomly generated cooling paths that match the He age of the

704 crystal data to within $\pm 1 \mathrm{SE}$, and the gray lines show paths that fail to fit that data. Green paths

705 are most consistent with the ${ }^{4} \mathrm{He} /{ }^{3} \mathrm{He}$ measurements, and yellow and red paths are progressively

706 less consistent. (a) The ${ }^{4} \mathrm{He} /{ }^{3} \mathrm{He}$ data for THC07 indicate a mean cooling age $\tau_{65}=9.2 \mathrm{Ma}$ and a

707 moderate cooling rate $\left(\gamma_{80-35}>15^{\circ} \mathrm{C} / \mathrm{Ma}\right)$ from 10 to $6 \mathrm{Ma}$. (b) THC08 has a mean cooling age $\tau_{65}$

$708=6.4 \mathrm{Ma}$ and very fast cooling $\left(\gamma_{80-35} \sim 30^{\circ} \mathrm{C} / \mathrm{Ma}\right)$ at that time. Full degassing results are available

709 in supplement Table S3.

710

711 Figure 6. Cross section of isotherm structure beneath the deepest part of Fjord Messier, assuming

712 constant uniform erosion. The stationary topography results in a stable thermal field and therefore

713 the isotherms are constant throughout time. For selected points in the landscape, we calculate $\tau_{65}$,

714 corresponding to the time since that bedrock point was at the $65^{\circ} \mathrm{C}$ isotherm (colored circles),

715 and the cooling rate, $\gamma_{80-35}$ (slope of colored lines of inset plot). For this steady-state case, $\tau_{65}$ and

$716 \gamma_{80-35}$ are almost solely a function of exhumation rate. The variation in the $\tau_{65}$ ages is related to

717 variations in the height of the locations along the fjord wall (circles) relative to the underlying 65

$718{ }^{\circ} \mathrm{C}$ isotherm. The inset shows modeled cooling paths, where $\gamma_{80-35}$ is the slope, for the locations

719 on the fjord wall, indicating cooling rates between 8 and $12{ }^{\circ} \mathrm{C} / \mathrm{Ma}$ at all elevations in the Steady-

720 state hypothesis, shown in Figure 7.

721 
722 Figure 7. Model simulation for four topographic scenarios. The Steady-State (null) hypothesis is

723 shown in the right column, and the remaining left columns show three alternative hypotheses (see

724 text for details). The top row shows cross sections through the modeled topography across Fjord

725 Messier for the four topographic scenarios at $1 \mathrm{Ma}$ intervals from $7 \mathrm{Ma}$ (thick light green line) to

726 the modern (thin black line). The Steady-state scenario (column 1) has a steady topographic form,

727 equivalent to the modern topography. The three alternative hypotheses (columns 2-4) start with a

728 relatively smooth topography, with initial elevations similar to the modern summit topography.

729 For each scenario, the valley relief is then increased at different times until it develops to the

730 modern topography. The second and third rows show predictions for $\tau_{65}$ (cooling age since $65^{\circ} \mathrm{C}$ )

731 and $\gamma_{80-35}$ (cooling rates for the interval 80 to $35^{\circ} \mathrm{C}$ ) for each scenario as observed in bedrock

732 samples from the modern topographic surface.

733

734 Figure 8. An example from the Rhône Valley in the Swiss Alps showing how apatite He ages

735 and ${ }^{4} \mathrm{He} /{ }^{3} \mathrm{He}$ data constrain long-term erosion and valley incision (modified after Valla et al.,

736 2011). (a) Vertical transect sample locations (yellow circles). (b) Apatite He ages increase from

$737 \sim 4$ to $8 \mathrm{Ma}$ with elevation. Error bars are equal to $\pm 1 \mathrm{SE}$. Envelope and errors for the regression

738 line are shown at the 95 percent confidence level. Dashed line shows an approximate

739 extrapolation of the age-elevation profile, as guided by the ${ }^{4} \mathrm{He} /{ }^{3} \mathrm{He}$ results. The extrapolation

740 shows that the conventional He apatite ages could be used to resolve the young event, but that

741 would require analysis of bedrock samples from below the valley floor. (c-e) Cooling paths

742 constrained by ${ }^{4} \mathrm{He} /{ }^{3} \mathrm{He}$ data for three samples, shown in order, from top to bottom, of decreasing

743 elevation. The colored lines show randomly generated cooling paths that match the He age to

744 within $\pm 1 \mathrm{SE}$, and the gray lines show paths that fail to fit those data. Green paths are most 
745 consistent with the ${ }^{4} \mathrm{He} /{ }^{3} \mathrm{He}$ measurements, and yellow and red paths progressively less

746 consistent. See text for interpretation.

747

\section{$748 \quad$ References}

749

750 1. Alley, R.B., Lawson, D.E., Larson, G.J., Evenson, E.B., Baker, G.S., 2003. Stabilizing

751

752

753

754

755

756

757

758

759

760

761

762

763

764

765

766

767

768

769

770

771

772

773

774

775

776

777

778

779

780

781

782

783 feedbacks in glacier-bed erosion. Nature 424, 758-760.

2. Anderson, R.S., Dühnforth, M., Colgan, W., Anderson, L., 2012. Far-flung moraines: Exploring the feedback of glacial erosion on the evolution of glacier length. Geomorphology 179, 269-285.

3. Araya-Vergara, J.F., 2008. 2.2. The submarine geomorphology of the Chilean Patagonian fjords and piedmonts, in: Silva, N., Palma, S. (Eds.), Progress in the Oceanographic Knowledge of Chilean Interior Waters, From Puerto Montt to Cape Horn. p. 25-27.

4. Berger, A.L., Gulick, S.P., Spotila, J.A., Upton, P., Jaeger, J.M., Chapman, J.B., Worthington, L.A., Pavlis, T.L., Ridgway, K.D., Willems, B.A. and McAleer, R.J., 2008. Quaternary tectonic response to intensified glacial erosion in an orogenic wedge. Nature Geoscience 1, 793-799.

5. Blisniuk, P.M., Stern, L.A., Chamberlain, C.P., Idleman, B., Zeitler, P.K., 2005. Climatic and ecologic changes during Miocene surface uplift in the Southern Patagonian Andes. Earth and Planetary Science Letters 230, 125-142.

6. Braun, J., 2002. Quantifying the effect of recent relief changes on age-elevation relationships. Earth and Planetary Science Letters 200, 331-343.

7. Braun, J., 2003. Pecube: A new finite-element code to solve the 3D heat transport equation including the effects of a time-varying, finite amplitude surface topography. Computers \& Geosciences 29, 787-794.

8. Braun, J., van Der Beek, P., Valla, P., Robert, X., Herman, F., Glotzbach, C., Pedersen, V., Perry, C., Simon-Labric, T. Prigent, C., 2012. Quantifying rates of landscape evolution and tectonic processes by thermochronology and numerical modeling of crustal heat transport using PECUBE. Tectonophysics 524, 1-28.

9. Braun, J., Robert, X., and Simon-Labri Brocklehurst c, T., 2013. Eroding dynamic topography: Geophysical Research Letters 40, 1494-1499.

784 
794

795

796

797

798

799

800

801

802

803

804

805

806

807

808

809

810

811

812

813

814

815

816

817

818

819

820

821

822

823

824

825

826

827

828

829
10. Breitsprecher, K., Thorkelson, D.J., 2009. Neogene kinematic history of NazcaAntarctic-Phoenix slab windows beneath Patagonia and the Antarctic Peninsula. Tectonophysics 464, 10-20.

11. Brocklehurst, S.H., Whipple, K.X., 2006. Assessing the relative efficiency of fluvial and glacial erosion through simulation of fluvial landscapes. Geomorphology 75, 283-299.

12. Caldenius, C.G., 1932. Las glaciaciones Cuaternarias en la Patagonia y Tierra del Fuego. Dirección General de Minas y Geología.

13. Cande, S.C., Leslie, R.B., 1986. Late Cenozoic tectonics of the Southern Chile Trench. Journal of Geophysical Research 91, 471-496.

14. Clapperton, C.M., 1993. Quaternary geology and geomorphology of South America. New York, Elsevier, 779 p.

15. Dodson, M.H., 1973. Closure temperature in cooling geochronological and petrological systems. Contributions to Mineralogy and Petrology 40 259-274.

16. Dodson, M.H., 1979. Theory of cooling ages. In Lectures in isotope geology (pp. 194202). Springer Berlin Heidelberg.

17. Dowdeswell, J.A., Vásquez, M., 2013. Submarine landforms in the fjords of southern Chile: implications for glacimarine processes and sedimentation in a mild glacierinfluenced environment. Quaternary Science Reviews 64, 1-19.

18. Egholm, D.L., Nielsen, S.B., Pedersen, V.K., Lesemann, J.E., 2009. Glacial effects limiting mountain height. Nature 460, 884-887.

19. Ehlers, T.A., and Farley, K.A., 2003. Apatite (U-Th)/He thermochronometry: methods and applications to problems in tectonic and surface processes. Earth and Planetary Science Letters 206, 1-14.

20. Ehlers, T.A., Farley, K.A., Rusmore, M.E. and Woodsworth, G.J., 2006. Apatite (UTh)/He signal of large-magnitude accelerated glacial erosion, southwest British Columbia. Geology 34, 765-768.

21. Eilers, P., Boelens, H., 2005. Baseline correction with asymmetric least squares smoothing. Leiden University Medical Centre report.

22. Farley, K.A., 2002. (U-Th)/He Dating: Techniques, calibrations, and applications: Reviews in Mineralogy and Geochemistry 47, 819-844.

23. Flowers, R.M, Farley, K.A., 2012. Apatite 4He/3He and (U-Th)/He evidence for an ancient Grand Canyon. Science 338, 1616-1619. 
830

831

832

833

834

835

836

837

838

839

840

841

842

843

844

845

846

847

848

849

850

851

852

853

854

855

856

857

858

859

860

861

862

863

864

865

866

867

868

869

870

871

872

873
24. Fosdick, J.C., Grove, M., Hourigan, J.K. and Calderon, M., 2013. Retroarc deformation and exhumation near the end of the Andes, southern Patagonia. Earth and Planetary Science Letters 361, 504-517.

25. Fyrillas, M., Pozrikidis, C., 2001. Conductive heat transport across rough surfaces and interfaces between two conforming media. International journal of heat and mass transfer 44, 1789-1801.

26. Garcia, D., 2010. Robust smoothing of gridded data in one and higher dimensions with missing values. Computational statistics \& data analysis 54, 1167-1178.

27. Georgieva, V., Melnick, D., Schildgen, T.F., Ehlers, T.A., Lagabrielle, Y., Enkelmann, E. and Strecker, M.R., 2016. Tectonic control on rock uplift, exhumation, and topography above an oceanic ridge collision: Southern Patagonian Andes ( $\left.47^{\circ} \mathrm{S}\right)$, Chile. Tectonics 35, $1317-1341$.

28. Glasser, N.F., Ghiglione, M.C., 2009. Structural, tectonic and glaciological controls on the evolution of fjord landscapes. Geomorphology 105, 291-302.

29. Guillaume, B., Gautheron, C., Simon-Labric, T., Martinod, J., Roddaz, M., Douville, E., 2013. Earth and Planetary Science Letters. Earth and Planetary Science Letters 364, 157167.

30. Guivel, C., Morata, D., Pelleter, E., Espinoza, F., Maury, R.C., Lagabrielle, Y., Polvé, M., Bellon, H., Cotten, J., Benoit, M. and Suárez, M., 2006. Miocene to Late Quaternary Patagonian basalts (46-47 S): geochronometric and geochemical evidence for slab tearing due to active spreading ridge subduction. Journal of Volcanology and Geothermal Research 149, 346-370.

31. Hallet, B., Hunter, L., Bogen, J., 1996. Rates of erosion and sediment evacuation by glaciers: A review of field data and their implications. Global and Planetary Change 12, 213-235.

32. Hamza, V. M., Dias, F. J .S. S., Gomes, A. J. L., Terceros, Z .G. D., 2005. Numerical and functional representations of regional heat flow in South America. Physics of The Earth and Planetary Interiors 152, 223-256.

33. Haschke, M., Sobel, E.R., Blisniuk, P., Strecker, M.R., Warkus, F., 2006. Continental response to active ridge subduction. Geophysical Research Letters 33, L15315.

34. Headley, R.M., Roe, G., Hallet, B., 2012. Glacier longitudinal profiles in regions of active uplift. Earth and Planetary Science Letters 317, 354-362. 
874

875

876

877

878

879

880

881

882

883

884

885

886

887

888

889

890

891

892

893

894

895

896

897

898

899

900

901

902

903

904

905

906

907

908

909

910

911

912

913

914

915

916

917

918
35. Herman, F., Seward, D., Valla, P. G., Carter, A., Kohn, B., Willett, S. D., Ehlers, T.A., 2013. Worldwide acceleration of mountain erosion under a cooling climate. Nature 504, 423-426.

36. Herman, F., Brandon, M.T., 2015. Mid-latitude glacial erosion hotspot due to equatorial shifts in southern Westerlies. Geology 43, 987-990.

37. Hooke, R.L., 1991. Positive feedbacks associated with erosion of glacial cirques and overdeepenings. Geological Society of America Bulletin 103, 1104-1108.

38. Hulton, N., Sugden, D., Payne, A., Clapperton, C., 1994. Glacier modeling and the climate of Patagonia during the last glacial maximum. Quaternary Research 42, 1-19.

39. Kaplan, M., Hein, A., Hubbard, A., Lax, S., 2009. Can glacial erosion limit the extent of glaciation? Geomorphology 103, 172-179.

40. Koppes, M.N., Montgomery, D.R., 2009. The relative efficacy of fluvial and glacial erosion over modern to orogenic timescales. Nature Geoscience 2, 644-647.

41. Kessler, M.A., Anderson, R.S., Briner, J.P., 2008. Fjord insertion into continental margins driven by topographic steering of ice. Nature Geoscience 1, 365-369.

42. MacGregor, K.R., Anderson, R.S., Anderson, S P., Waddington, E.D., 2000. Numerical simulations of glacial-valley longitudinal profile evolution. Geology 28, 1031-1034.

43. McPhillips, D., Brandon, M.T., 2010. Using tracer thermochronology to measure modern relief change in the Sierra Nevada, California. Earth and Planetary Science Letters 296, 373-383.

44. Mercer, J.H., Sutter, J.F., 1982. Latest Miocene - Earliest Pliocene Glaciation in Southern Argentina: Implications for Global Ice Sheet History. Paleogeography, Paleoclimatology, Paleoecology 38, 185-206.

45. Molnar, P., England, P. 1995. Temperatures in zones of steady-state underthrusting of young oceanic lithosphere. Earth and Planetary Science Letters 131, 57-70.

46. Montgomery, D.R., 2002. Valley formation by fluvial and glacial erosion. Geology 30, $1047-1050$.

47. Oerlemans, J., 1984. Numerical experiments on large-scale glacial erosion. Zeitschrift für Gletscherkunde und Glazialgeologie 20, 107-126.

48. Oskin, M., Burbank, D.W., 2005. Alpine landscape evolution dominated by cirque retreat. Geology 33, 933-936. 
923

924

925

926

927

928

929

930

931

932

933

934

935

936

937

938

939

940

941

942

943

944

945

946

947

948

949

950

951

952

953

954

955

956

957

958

959

960

961

962
49. Pedersen, V.K., Egholm, D.L., 2013. Glaciations in response to climate variations preconditioned by evolving topography. Nature 493, 206-210.

50. Porter, S.C., 1989. Some geological implications of average Quaternary glacial conditions. Quaternary Research 32, 245-261.

51. Preusser, F., 2012. Quaternary glaciation history of northern Switzerland. Quaternary International 279-280, 386-386.

52. Ramos, V.A., 1989. Andean Foothills Structures in Northern Magallanes Basin, Argentina. The American Association of Petroleum Geologists Bulletin 73, 887-903.

53. Ramos, V., Ghiglione, M., 2008. Tectonic evolution of the Patagonian Andes. Developments in Quaternary Science 11, 57-71.

54. Ramsay, A.C., 1862. On the glacial origin of certain lakes in Switzerland, the black forest, great Britain, Sweden, North America, and elsewhere. Journal of the Geological Society $18,185-205$.

55. Rivera, A., Benham, T., Casassa, G., Bamber, J. and Dowdeswell, J.A., 2007. Ice elevation and areal changes of glaciers from the Northern Patagonia Icefield, Chile. Global and Planetary Change 59, 126-137.

56. Schildgen, T.F., Balco, G., Shuster, D.L., 2010. Canyon incision and knickpoint propagation recorded by apatite ${ }^{4} \mathrm{He} /{ }^{3} \mathrm{He}$ thermochronometry. Earth and Planetary Science Letters 293, 377-387.

57. Shuster, D.L., Farley, K.A., 2004. ${ }^{4} \mathrm{He} /{ }^{3} \mathrm{He}$ Thermochronometry. Earth and Planetary Science Letters 217, 1-17.

58. Shuster, D.L., Farley, K.A., Sisterson, J.M., Burnett, D.S., 2004. Quantifying the diffusion kinetics and spatial distributions of radiogenic ${ }^{4} \mathrm{He}$ in minerals containing proton-induced ${ }^{3} \mathrm{He}$. Earth and Planetary Science Letters 217, 19-32.

59. Shuster, D.L., Farley, K.A., 2005. ${ }^{4} \mathrm{He} /{ }^{3} \mathrm{He}$ Thermochronometry: Theory, Practice, and Potential Complications. Reviews in Mineralogy \& Geochemistry 58, 181-203.

60. Shuster, D.L., Ehlers, T.A., Rusmore, M.E., Farley, K.A., 2005. Rapid glacial erosion at 1.8 Ma revealed by ${ }^{4} \mathrm{He} /{ }^{3} \mathrm{He}$ thermochronometry. Science 310, 1668-1670.

61. Shuster, D.L., Flowers, R.M., Farley, K.A., 2006. The influence of natural radiation damage on helium diffusion kinetics in apatite. Earth and Planetary Science Letters 249, $148-161$. 
963

964

965

966

967

968

969

970

971

972

973

974

975

976

977

978

979

980

981

982

983

984

985

986

987

988

989

990

991

992

993
62. Shuster, D.L., Cuffey, K.M., Sanders, J.W., Balco, G., 2011. Thermochronometry reveals headward propagation of erosion in an alpine landscape. Science 332, 84-88.

63. Stüwe, K., Hintermuller, M., 2000. Topography and isotherms revisited: the influence of laterally migrating drainage divides. Earth and Planetary Science Letters 184, 287-303.

64. Thomson, S.N., Brandon, M.T., Tomkin, J.H., Reiners, P.W., Vásquez, C., Wilson, N.J., 2010a. Glaciation as a destructive and constructive control on mountain building. Nature 467, 313-317.

65. Thomson, S.N., Brandon, M.T., Reiners, P.W., Zattin, M., Isaacson, P.J., Balestrieri, M.L., 2010b. Thermochronologic evidence for orogen-parallel variability in wedge kinematics during extending convergent orogenesis of the northern Apennines, Italy. Geological Society of America Bulletin 122, 1160-1179.

66. Ton-That, T., Singer, B.S., Mörner, N.A., Rabassa, J., 1999. Datación de lavas basálticas por 40Ar/39Ar y geología glacial de la región del lago Buenos Aires, provincia de Santa Cruz, Argentina. Revista de la Asociación Geológica Argentina 54, 333-352.

67. Tremblay, M.M., Fox, M., Schmidt, J.L., Tripathy-Lang, A., Wielicki, M.M., Harrison, T.M., Zeitler, P.K. and Shuster, D.L., 2015. Erosion in southern Tibet shut down at 10 Ma due to enhanced rock uplift within the Himalaya. Proceedings of the National Academy of Sciences 112, 12030-12035.

68. Valla, P.G., Shuster, D.L., van der Beek, P.A., 2011. Significant increase in relief of the European Alps during mid-Pleistocene glaciations. Nature Geoscience 4, 688-692.

69. Yanites, B.J., Ehlers, T.A., 2012. Global climate and tectonic controls on the denudation of glaciated mountains. Earth and Planetary Science Letters 325-326, 63-75. 


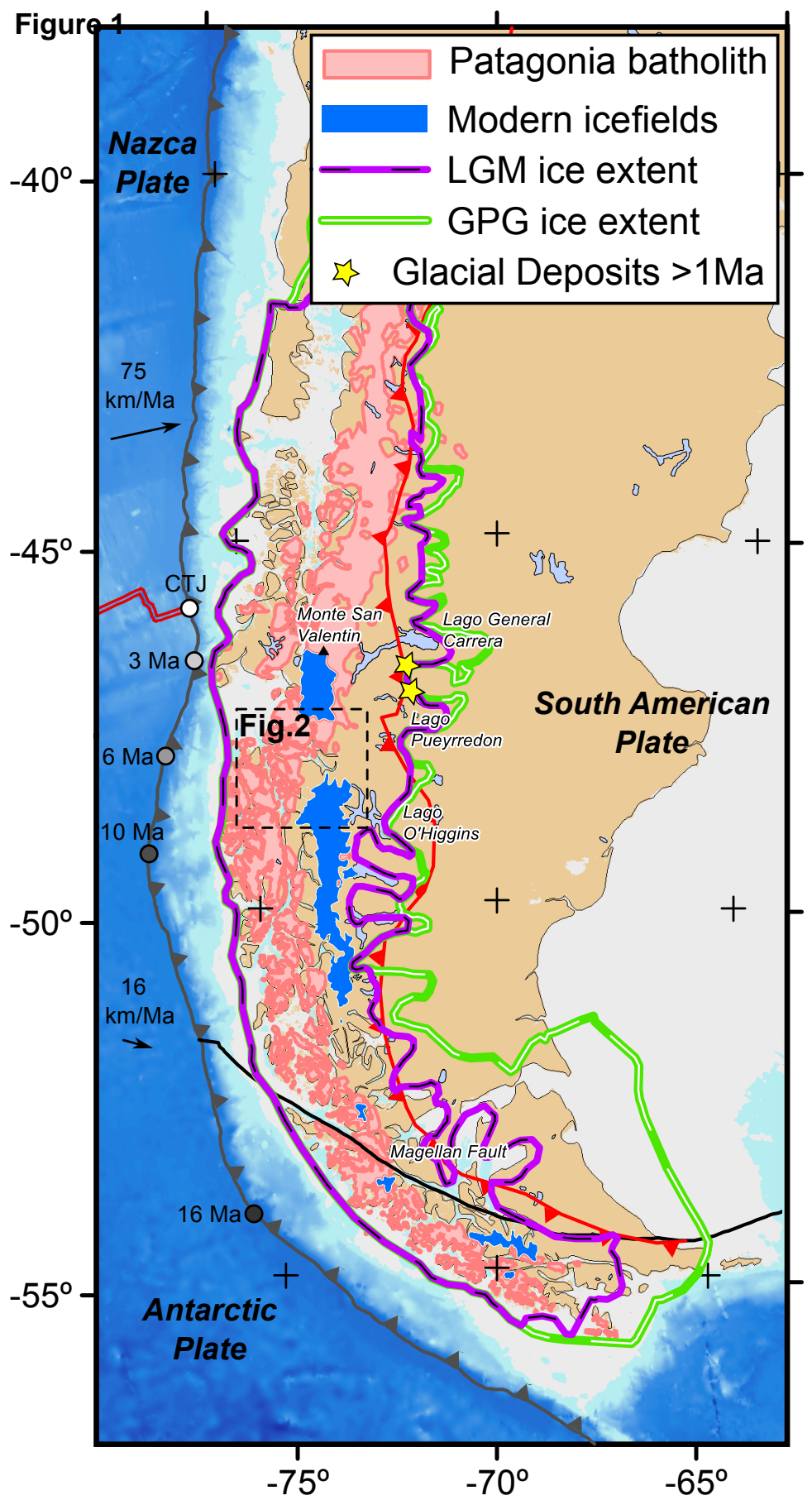




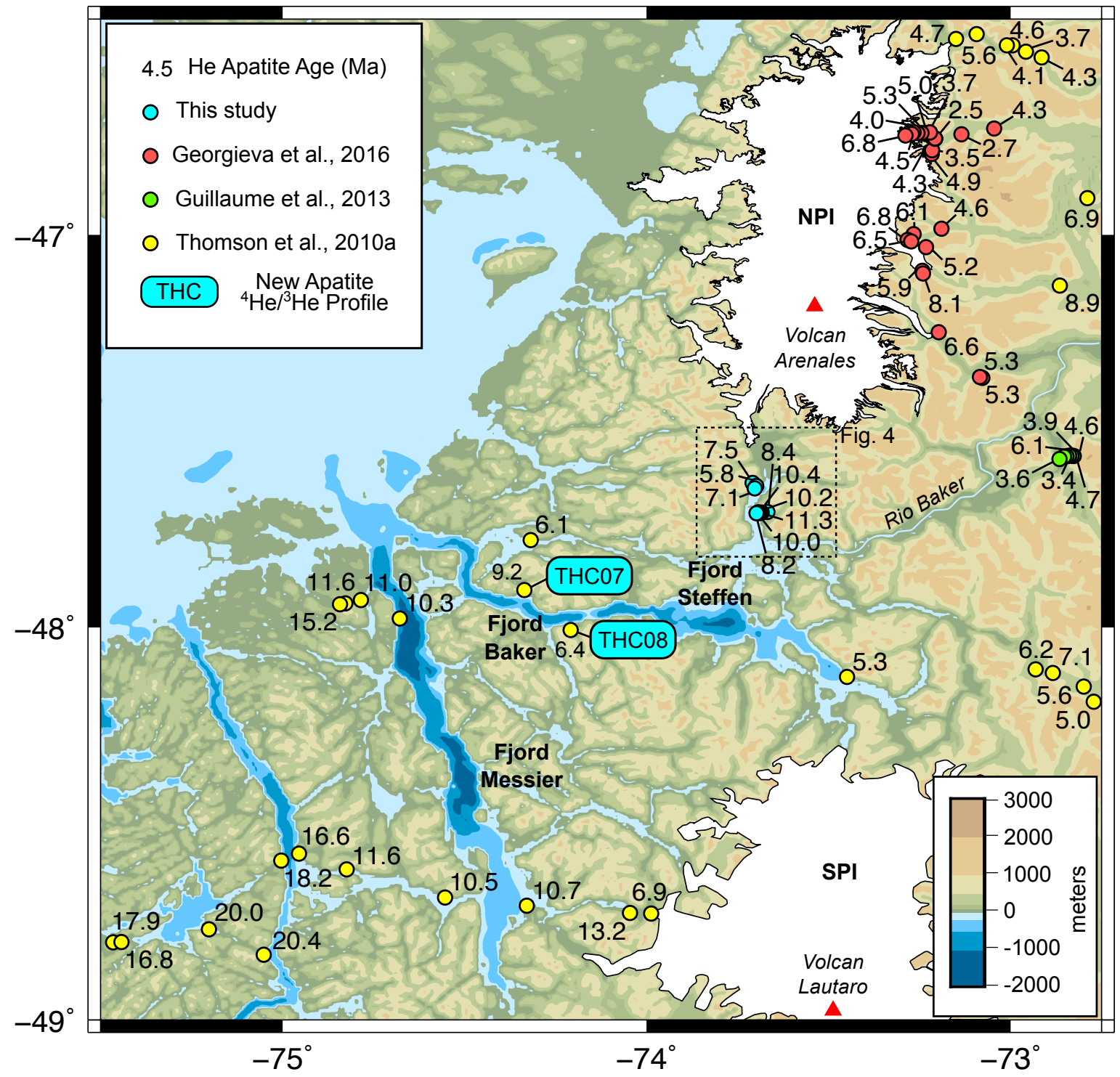


FAgure 3

B

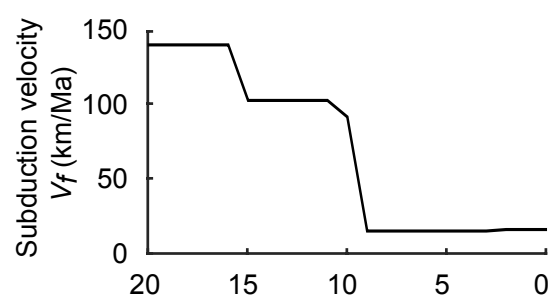
100 km

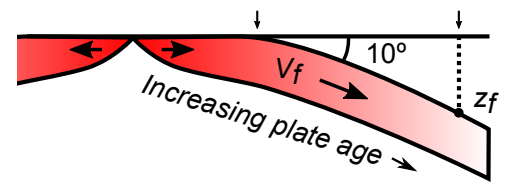

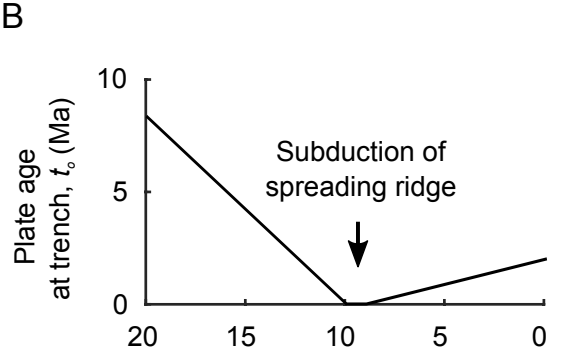

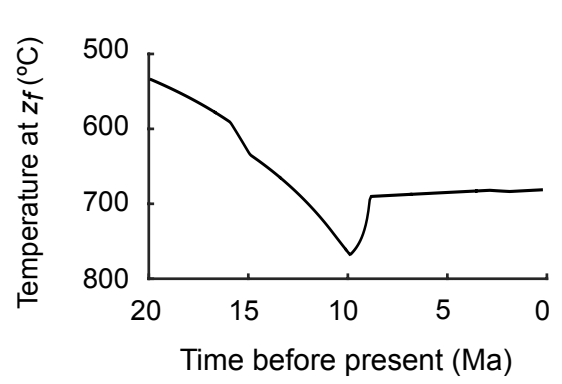

Region of apatite $\mathrm{He}$ and FT thermochronometry sensitivity

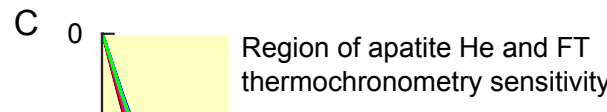

18
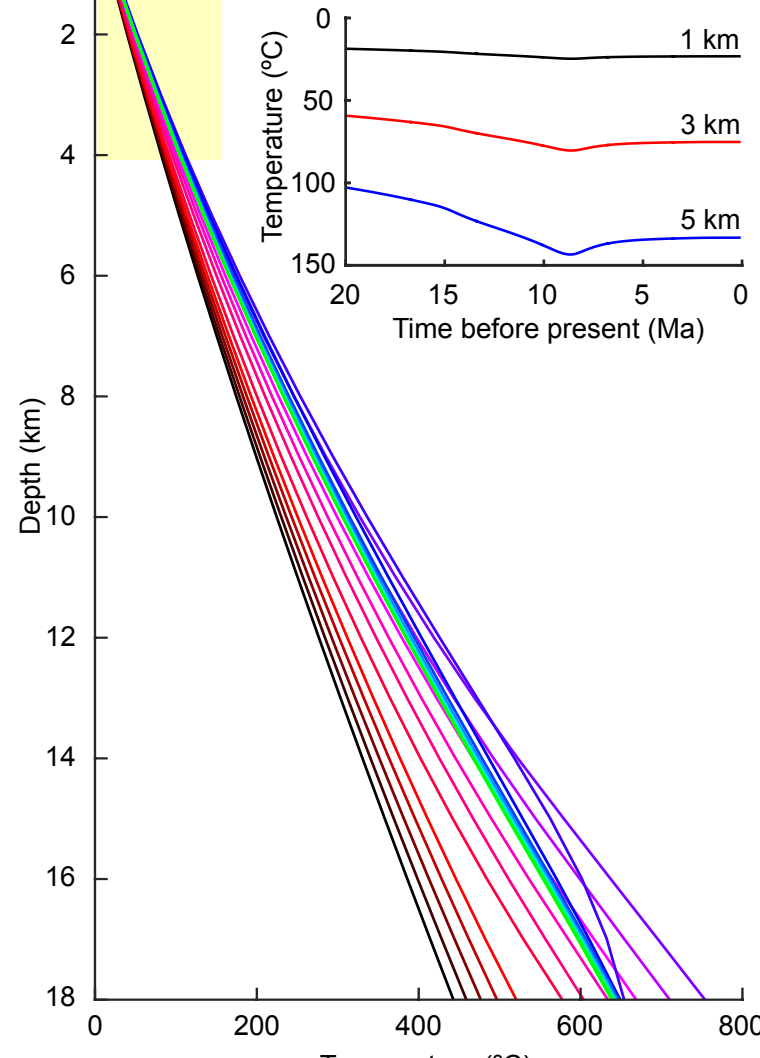

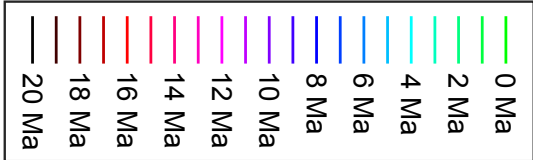




\section{Figures 5}

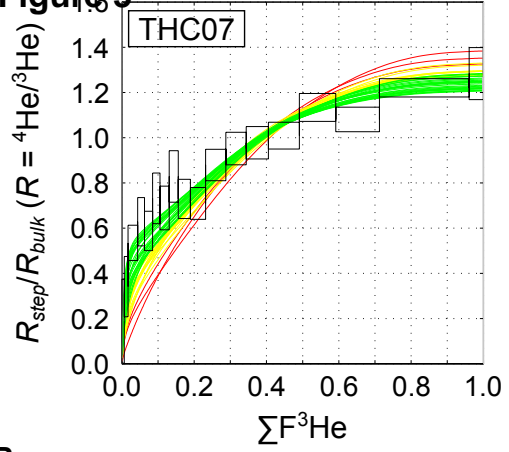

B

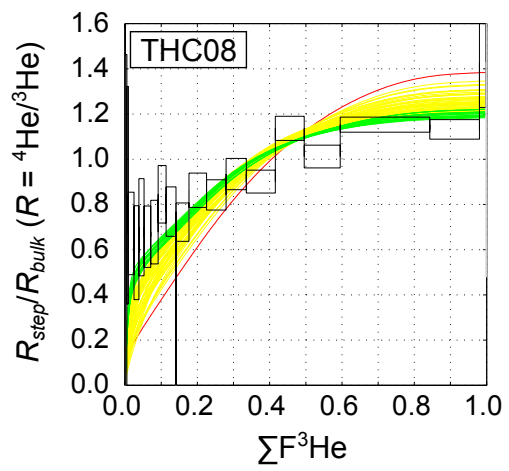

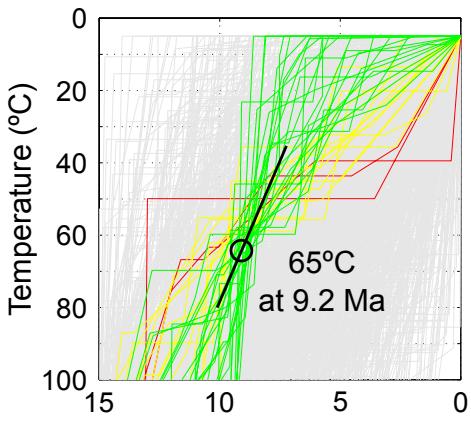

Time (Ma before present)

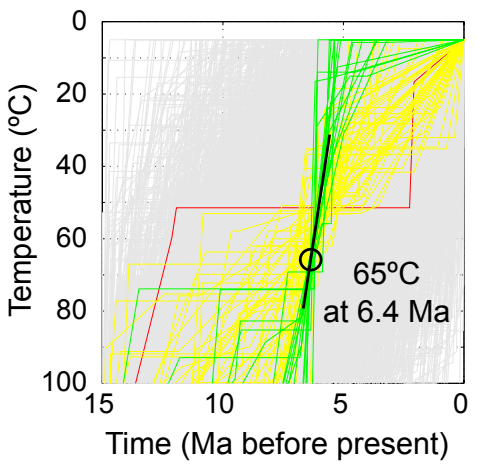


Figure 6

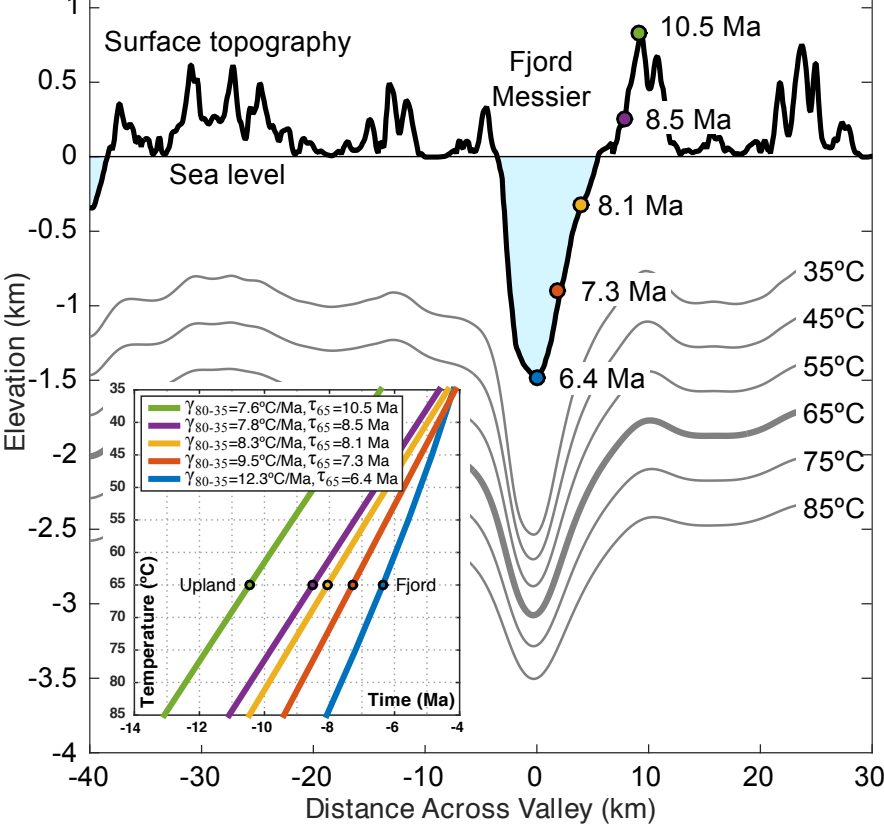


Figure 7

1. Steady-state

2. Early Incision

3. Steady Incision

(All valley relief cut prior to $7 \mathrm{Ma}$ )
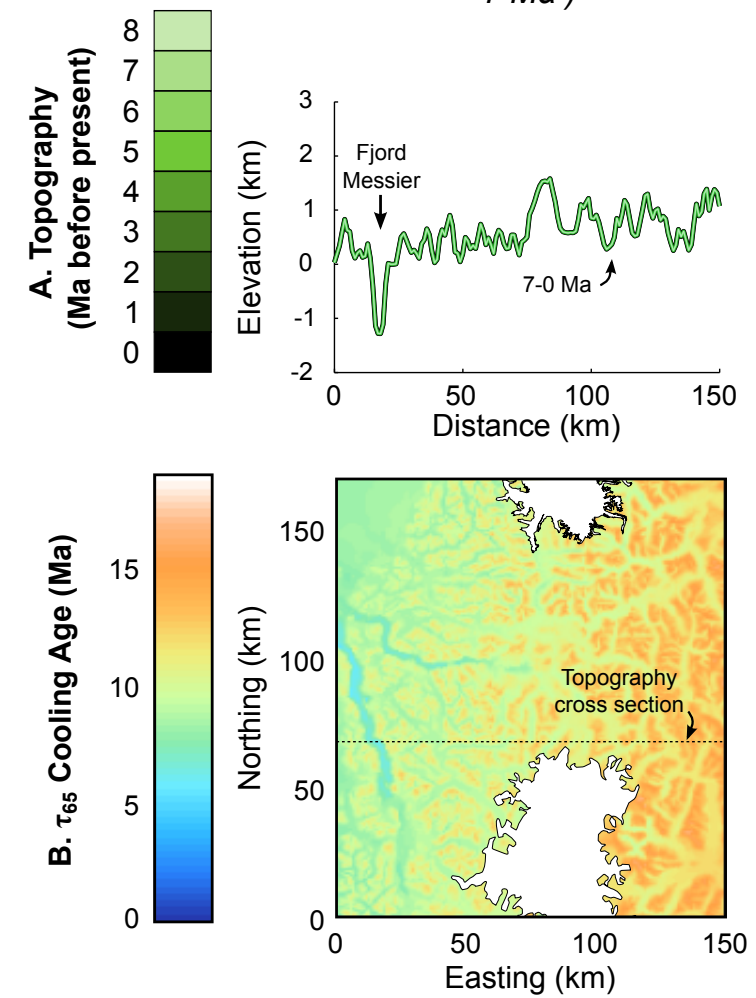

$\sum_{0}^{\pi}$
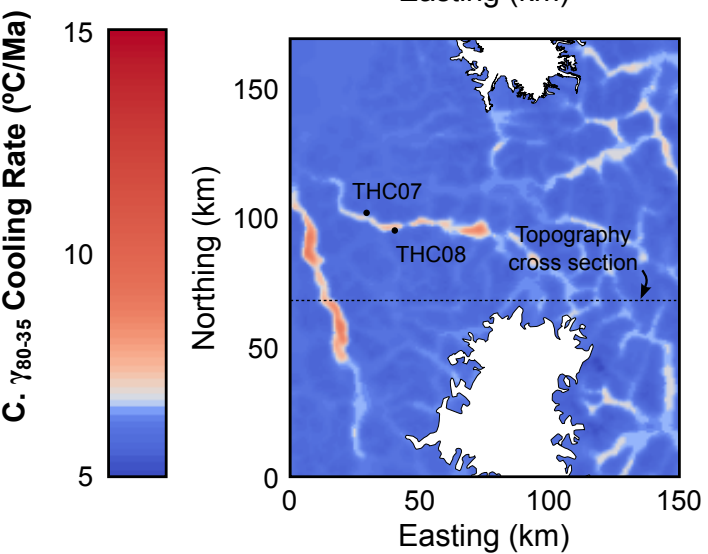
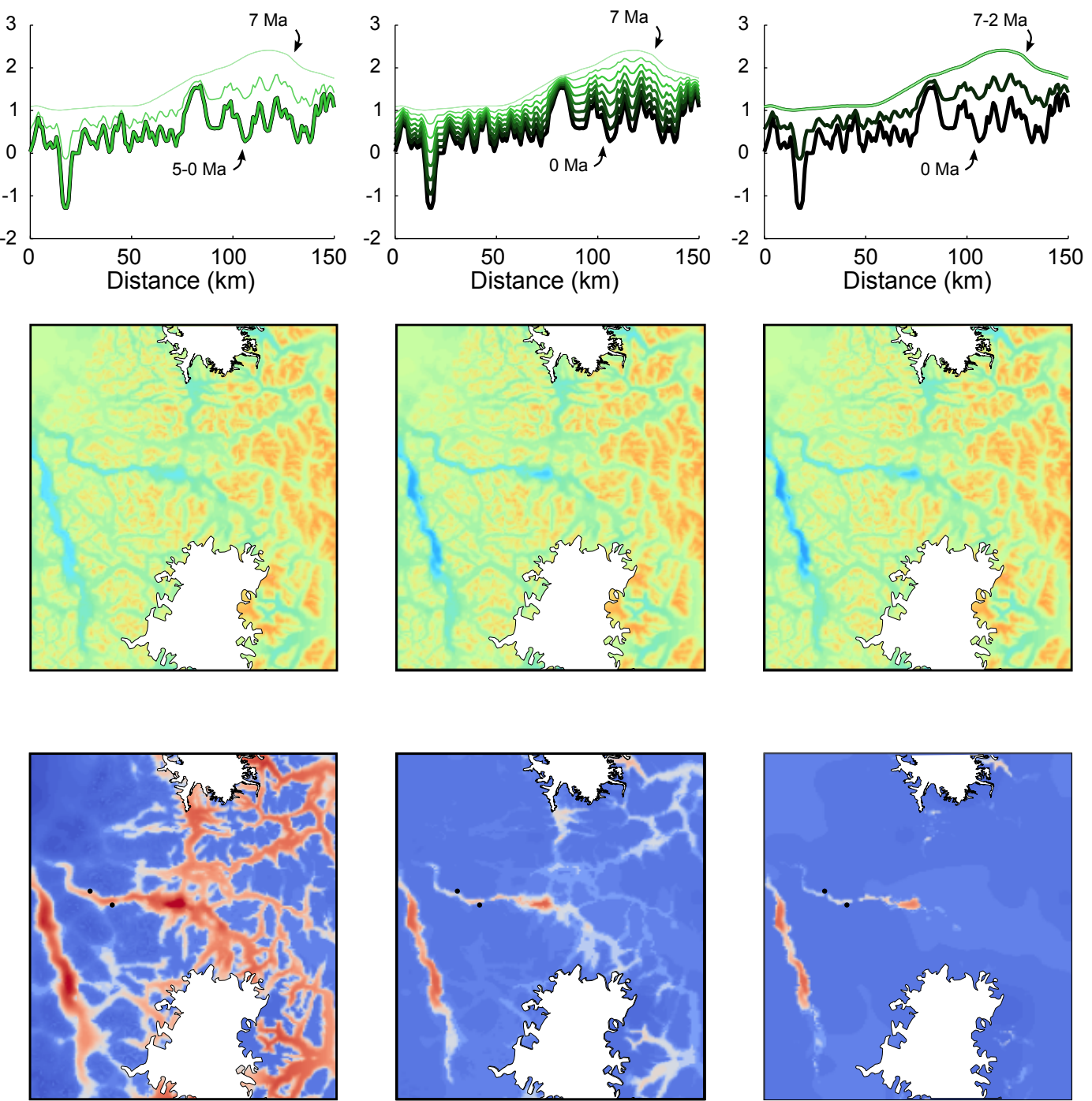

4. Late Incision

(All valley relief cut since

y relief cut since
$2 \mathrm{Ma}$ ) 


\section{Aigure 8}

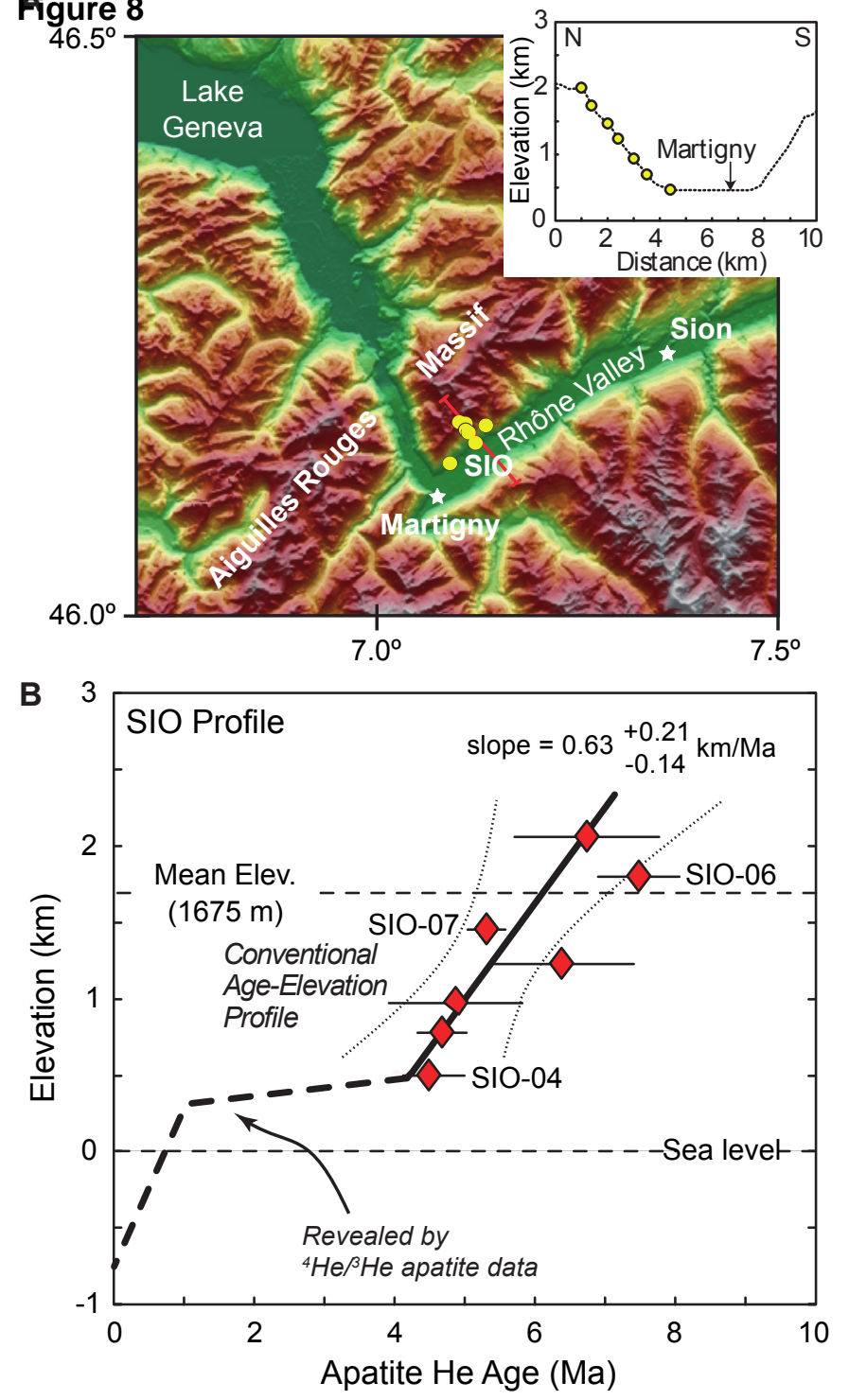

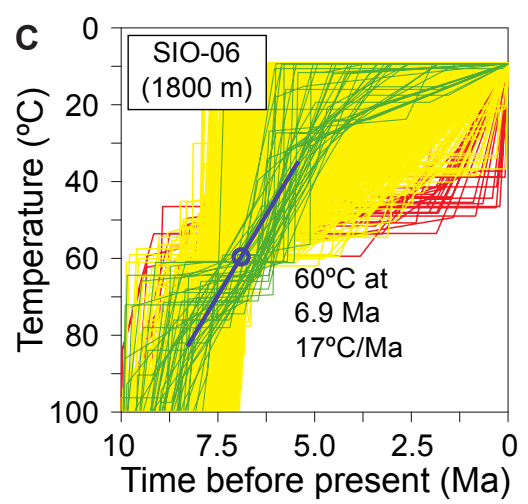
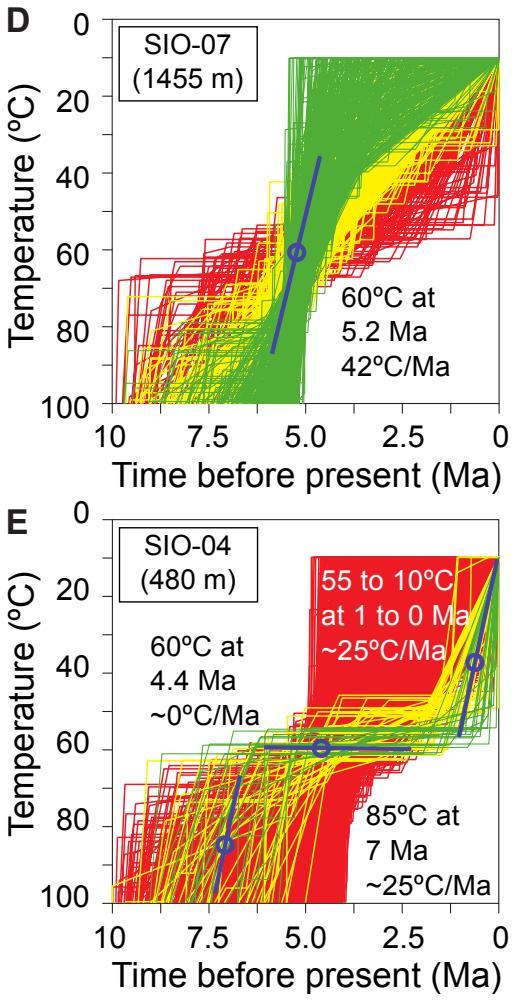
Table 1. Apatite (U-Th)/He sample data and mean ages

\begin{tabular}{|c|c|c|c|c|c|}
\hline Sample & Latitude $\left({ }^{\circ} \mathrm{S}\right)$ & Longitude $\left({ }^{\circ} \mathrm{W}\right)$ & Elevation (m) & $\begin{array}{c}\text { Mean Age } \\
(\mathrm{Ma})\end{array}$ & SE (Ma) \\
\hline \multicolumn{6}{|c|}{ Fjord Steffen Northern Transect } \\
\hline FS01 & 47.62830 & 73.71111 & 1013 & \multicolumn{2}{|c|}{ not replicated } \\
\hline FS02 & 47.63228 & 73.70897 & 842 & 7.5 & 0.97 \\
\hline FS04 & 47.63371 & 73.70287 & 534 & \multicolumn{2}{|c|}{ not replicated } \\
\hline FS06 & 47.63965 & 73.69865 & 251 & 5.8 & 0.21 \\
\hline FS17 & 47.64607 & 73.70287 & 105 & 7.14 & 0.81 \\
\hline \multicolumn{6}{|c|}{ Fjord Steffen Southern Transect } \\
\hline FS08 & 47.70565 & 73.66784 & 1175 & 8.4 & 0.99 \\
\hline FS10 & 47.70781 & 73.67954 & 872 & \multicolumn{2}{|c|}{ not replicated } \\
\hline FS11 & 47.70767 & 73.68395 & 709 & 10.44 & 3.78 \\
\hline FS12 & 47.70814 & 73.68685 & 573 & 10.21 & 0.43 \\
\hline FS13 & 47.70799 & 73.68935 & 417 & 11.29 & 0.92 \\
\hline FS14 & 47.70662 & 73.69276 & 267 & 10 & 0.71 \\
\hline FS15 & 47.70860 & 73.69539 & 128 & \multicolumn{2}{|c|}{ not replicated } \\
\hline FS16 & 47.70908 & 73.69784 & 0 & 8.23 & 0.29 \\
\hline
\end{tabular}

